\title{
INTER-NATION EQUITY REVISITED
}

\author{
Ivan Ozai*
}

\begin{abstract}
States are on the verge of a new form of global competition. Some have taken unilateral measures to tax multinational profits that they would typically not be able to tax, at least not according to conventional international tax concepts and rules. Others have threatened to retaliate with economic countermeasures to protect their tax base and corporate residents. The recent attempt of the OECD to build consensus for a global tax compact has so far proven unsuccessful due to broad disagreement about how taxing rights should be equitably distributed between countries.

As policymakers and tax scholars increasingly call into question long-standing theories of international taxation, the concept of inter-nation equity plays a pivotal role as a guiding principle in determining how to divide the international tax base among states. Inter-nation equity is one of the most ubiquitous concepts appearing in international tax policy discussions and yet one of the most understudied in tax scholarship.

This Article introduces a comprehensive normative analysis of inter-nation equity by discussing how the concept should reconcile the two primary goals of international allocation of taxing rights: on the one hand, the concern of states to preserve their tax sovereignty and, on the other hand, the need to promote some degree of redistribution to address the challenges of global poverty and inequality. This Article further explains how a similar notion of inter-nation equity has developed in other areas of international law and discusses some practical implications for tax policy design.
\end{abstract}

I. INTRODUCTION

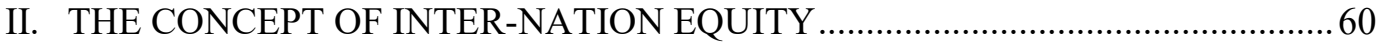

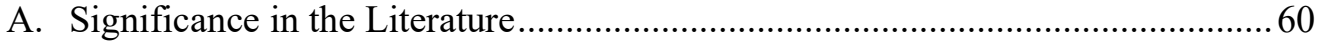

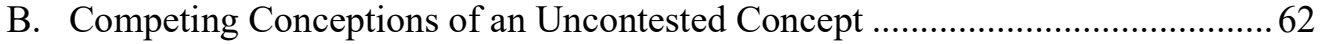

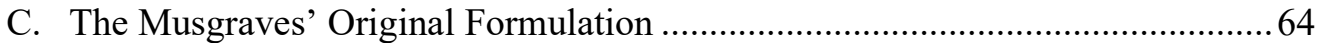

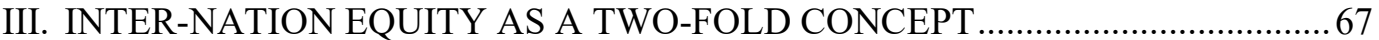

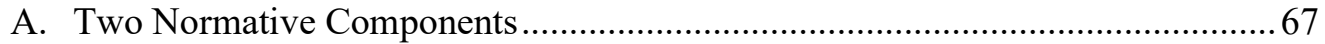

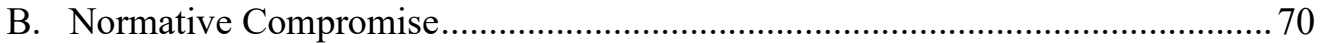

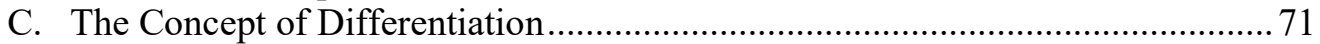

IV. ALLOCATING RIGHTS ACCORDING TO INTER-NATION EQUITY ............... 74

A. Reconciling Entitlement and Differentiation .................................................... 74

* Richard H. Tomlinson Doctoral Fellow at McGill University Faculty of Law. For thoughtful comments and suggestions on earlier drafts, special thanks go to Professors Allison Christians, Laurens van Apeldoorn, Catherine Walsh, Tarcísio Magalhães, Diane Ring, Steven Dean, Miranda Stewart, Kim Brooks, Wei Cui, as well as participants of seminars at Dalhousie University's Schulich School of Law, York University's Osgoode Hall Law School, and Ryerson University's Faculty of Law, where versions of this work were presented. The core of this paper was written during a four-month research fellowship in 2019 at the Centre d'études et de recherches internationales de l'Université de Montréal (CÉRIUM), and I am grateful to Magdalena Dembinska, Frédéric Mérand, and their team for their hospitality and support. Finally, thank you to the editors of the Columbia Journal of Tax Law for their insightful comments. 




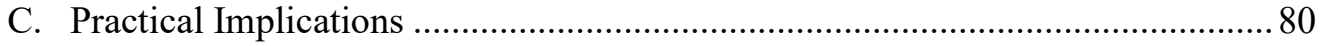



2. Unitary Taxation with Formulary Apportionment ................................... 81



V. CONCLUSION

\section{INTRODUCTION}

In 1963, economist Peggy Musgrave (née Brewer, formerly Richman) developed the concept of inter-nation equity as a metric to determine how rights to tax should be distributed among states. ${ }^{1}$ Her work diverged from the more familiar tax policy analysis which focused on the distribution of tax burdens within closed societies. ${ }^{2}$ A decade later, Peggy Musgrave teamed up with her husband Richard Musgrave to revise her 1963 work and made a compelling argument for allocating the international tax base in a way that acknowledges the entitlement of countries to tax income arising in their territories while making allowance for some degree of international redistribution. ${ }^{3}$ The concept of internation equity gained nearly universal embrace in tax scholarship and became the go-to normative principle in tax policy discussions regarding the distribution of taxes across jurisdictions. Yet, much of the purpose behind its original formulation has been lost over the years.

Inter-nation equity has become a vague enough term that it is used to justify virtually any possible stance on how to distribute the international tax base while giving the impression that such a stance, because it is purportedly aligned with the concept of inter-nation equity, is grounded in some sense of fairness between nations. Some have argued that the Musgraves' formulation of inter-nation equity is too narrow to lead to any practical guidance or recommendations. ${ }^{4}$ A more charitable view of their scholarship, however, suggests that the Musgraves provided an important starting point for a broader discussion about international distributive justice. ${ }^{5}$

This Article explores the rationale behind the original conception of inter-nation equity and demonstrates that it is more than a mere rhetorical device. The Musgraves' ingenious work on the notion of inter-nation equity was foundational and is still the leading contribution to the field. ${ }^{6}$ Yet, it has two significant limitations from a normative standpoint. First, despite their meaningful concern with international justice, their focus

(1963).

${ }^{1}$ Peggy Brewer Richman, Taxation of Foreign Investment Income: An Economic Analysis

${ }^{2}$ Previous discussions about distributive justice in the tax literature were mostly limited to the concept of inter-individual equity, which refers to how tax burdens should be distributed among fellow nationals. See id.

${ }^{3}$ Richard A. Musgrave \& Peggy B. Musgrave, Inter-Nation Equity, in Modern Fiscal Issues: EsSays In HonOR OF CARL S. Shoup 63, 85 (Richard M. Bird \& John G. Head eds., 1972) ("On the whole, it would seem desirable to implement redistributional objectives through rate differentiation while attempting to divide the source in line with 'true' economic imputation.").

${ }^{4}$ Alex Easson, Taxation of Foreign Direct Investment: An InTroduction 39 (1999); Reuven S. Avi-Yonah, Globalization, Tax Competition, and the Fiscal Crisis of the Welfare State, 113 HARV. L. REV. 1573, 1648 (2000); Tim Edgar, Corporate Income Tax Coordination as a Response to International Tax Competition and International Tax Arbitrage, 51 CAN. TAX J. 1079, 1154 (2003).

${ }^{5}$ Kim Brooks, Inter-Nation Equity: The Development of an Important but Underappreciated International Tax Policy Objective, in TAX REFORM IN THE 21st CENTURY: A VOlumE In MEMORY OF RiCHARD Musgrave 471, 493 (John G. Head \& Richard Krever eds., 2009).

${ }^{6}$ See id. at 472 . 
unsurprisingly leans more toward the economic implications of different tax policies than to the normative underpinnings of inter-nation equity. Second, they wrote their 1972 seminal essay at a time when sophisticated discussions about global justice had yet to unfold in the political philosophy literature.

This Article's first goal is to present a comprehensive normative analysis of internation equity. Building on contemporary developments in global justice, this Article evaluates how the concept of inter-nation equity can reconcile two major goals of international allocation of taxing rights: the concern of states to preserve their tax sovereignty and tax entitlement and the need to promote some degree of redistribution to take up the challenges of addressing global poverty and inequality. This analysis puts forth a two-pronged principle for how to allocate taxing rights among jurisdictions. It considers that whenever a normative approach based on tax sovereignty (entitlement approach) does not provide satisfactory guidance for how to divide the international tax base, taxing rights should be allocated to the benefit of less affluent countries so as to address global poverty and inequality (differential approach).

This Article's second contribution is to establish general but concrete normative requirements for differential mechanisms. The global recognition of the urgency of tackling global inequality has led some developed nations, both independently and collectively, to adopt tax measures that aim to reduce such inequality. Some of those initiatives, however, are problematic because they fail to address global inequality in a meaningful way. The normative requirements put forth in this Article indicate that redistribution through tax policy should be comprehensive and consistent so as not to produce further inequalities.

The remainder of this Article proceeds as follows. Part II introduces the concept of inter-nation equity. It demonstrates the significance of the concept in the tax literature, considers some of the varied and frequently conflicting interpretations the term has received over the years, and identifies the main assumptions and purposes behind its original formulation. Part III turns to the two normative components (entitlement and differentiation) comprising the original conception of inter-nation equity. It demonstrates that a dual conception of inter-nation equity finds some precedent in other areas of international law. Part IV puts forth normative requirements deriving from inter-nation equity and explores the practical implications of those requirements for tax policy design. Part V concludes by discussing potential constraints and objections to a dual conception of inter-nation equity.

\section{THE CONCEPT OF INTER-NATION EQUITY}

A. Significance in the Literature

Peggy Musgrave is generally regarded as having coined the phrase "inter-nation equity" so as to make a conceptual distinction from the more common notion of interindividual equity. ${ }^{7}$ The conceptual development of inter-nation equity was made known more broadly in a 1972 essay co-authored with Richard Musgrave, ${ }^{8}$ but Peggy Musgrave

\footnotetext{
${ }^{7}$ Richman, supra note 1; see also Klaus Vogel, Worldwide vs. Source Taxation of Income - A Review and Re-Evaluation of Arguments (Part III), 11 InTERTAX 393, 394 (1988) (stating that Peggy Musgrave deserves tribute for being the first to distinguish inter-individual equity considerations from those based on inter-nation equity); Michael J. Graetz, Taxing International Income: Inadequate Principles, Outdated Concepts, and Unsatisfactory Policies, 26 BrooK. J. INT'L. L. 1357, 1395 (2001); Nancy H. Kaufman, Fairness and the Taxation of International Income, 29 L. \& POL'Y INT'L Bus. 145, 153 (1998).

${ }^{8}$ Musgrave \& Musgrave, supra note 3.
} 
continued to develop the practical implications of inter-nation equity in her later work. ${ }^{9}$ A great part of the originality of her contribution to the tax literature was establishing the possible underlying principles of inter-nation equity and evaluating the consequences of incorporating those principles in concrete tax policy design. ${ }^{10}$

The concept of inter-nation equity is now ubiquitous in the tax literature. Commentators have applied the concept to a wide array of subjects, frequently beyond the scenarios envisaged by the Musgraves themselves. For instance, the concept has been used to argue for the replacement of the arm's length principles with a formulary apportionment approach, ${ }^{11}$ for a digital services tax, ${ }^{12}$ a global e-commerce tax, ${ }^{13}$ for the allocation of taxing rights to the country where economic activities occur and where value is created, ${ }^{14}$ against the restrictions on source-based taxation in the OECD and the UN model tax treaties ${ }^{15}$ for the regulation of tax competition, ${ }^{16}$ for the expansion of the existing concept of permanent establishment to include sales jurisdictions, ${ }^{17}$ for the harmonization of the legal treatment of inheritance tax rules in European countries, ${ }^{18}$ for the assessment of treaty

${ }^{9}$ See, e.g., Peggy B. Musgrave, The OECD Model Tax Treaty: Problems and Prospects, 10 Colum. J. World Bus. 29 (1975); Peggy B. Musgrave, Interjurisdictional Equity in Company Taxation: Principles and Applications to the European Union, in TAXING CAPITAL INCOME IN THE EUROPEAN UNION: IsSUES AND OPTIONS FOR REFORM 46 (Sijbren Cnossen ed., 2000) [hereinafter Musgrave, Interjurisdictional Equity]; Peggy B. Musgrave, Consumption Tax Proposals in an International Setting, 54 TAx L. ReV. 77 (2000); Peggy B. Musgrave, Sovereignty, Entitlement, and Cooperation in International Taxation, 26 BrooK. J. INT'L L. 1335 (2001) [hereinafter Musgrave, Sovereignty]; Peggy B. Musgrave, Taxing International Income: Further Thoughts, 26 BrooK. J. InT'L L. 1477 (2001) [hereinafter Musgrave, Taxing]; Peggy B. Musgrave, Combining Fiscal Sovereignty and Coordination: National Taxation in a Globalizing World, in The New Public FinANCE: Responding to Global Challenges 167 (Inge Kaul \& Pedro Conceiçāo eds., 2006) [hereinafter Musgrave, Combining]. Although the term "inter-nation equity" remains popular in the tax literature, Musgrave shifted to "interjurisdictional equity" in her later work. Because "jurisdiction" and "nation" are not precise substitutes, and the international allocation of taxing rights takes jurisdictions as the relevant political unit, "interjurisdictional equity" seems conceptually more accurate.

${ }^{10}$ Brooks, supra note 5, at 477. For a review of the relevance of Peggy Musgrave's work in current tax policy discussions, see Allison Christians, Digital Services Taxes and Internation Equity: A Tribute to Peggy Musgrave, 95 TAX Notes InT'L 589 (Aug. 12, 2019).

11 Otto H. Jacobs, Christoph Spendgel \& Anne Schäfer, ICT and Profit Allocation within Multinational Groups, 32 INTERTAX 268 (2004).

${ }^{12}$ Wei Cui \& Nigar Hashimzade, The Digital Services Tax as a Tax on Location-Specific Rent (CESifo, Working Paper No. 7737, 2019). But see Daniel Shaviro, Digital Services Taxes and the Broader Shift from Determining the Source of Income to Taxing Location-Specific Rents (NYU Law and Economics, Working Paper No. 19-36, 2019) (although supporting a digital services tax, arguing that inter-nation equity does not have much relevance to the discussion).

${ }^{13}$ Rifat Azam, Global Taxation of Cross-Border E-Commerce Income, 31 VA. TAx REV. 639 (2012).

14 OeCD/G20 Base Erosion and Profit Shifting Project, OECD, AdDressing the Tax Challenges of the Digital Economy, Action 1 - 2015 Final Report (2015).

${ }^{15}$ Oladiwura Ayeyemi Eyitayo-Oyesode, Source-Based Taxing Rights from the OECD to the UN Model Conventions: Unavailing Efforts and an Argument for Reform, 13 L. \& DEV. REV. 193 (2020).

${ }^{16}$ Joel P. Trachtman, International Regulatory Competition, Externalization, and Jurisdiction, 34 HARV. INT'L L.J. 47, 73 (1993).

17 Justus Eisenbeiss, BEPS Action 7: Evaluation of the Agency Permanent Establishment, 44 INTERTAX 481, 496 (2016).

${ }^{18}$ Jan Szczepański, Personal Genuine Links under Domestic Inheritance Tax Rules in the Light of International and European Standards, 43 INTERTAX 595, 604 (2015). 
obligations to proportionally allocate personal tax benefits among EU member states, ${ }^{19}$ and for the discussion of tax information exchange standards. ${ }^{20}$

Perhaps the most remarkable feature of inter-nation equity is that regardless of the disparities in how the concept is understood, ${ }^{21}$ there does not seem to be any disagreement about its primacy as a normative directive for how to allocate rights between jurisdictions. ${ }^{22}$ Considering the nearly universal acceptance of inter-nation equity in the realm of international tax policy, the lack of a robust effort in the literature to provide a comprehensive examination of its conceptual content and normative underpinnings is somewhat surprising. ${ }^{23}$ The following section will discuss a few conceptions of internation equity put forth in the literature and then propose a more comprehensive understanding based on Peggy Musgrave's own development of the concept.

\section{B. Competing Conceptions of an Uncontested Concept}

The absence of extended analyses of inter-nation equity did not bar commentators from employing it in ways that denote different and sometimes contradictory conceptions of the idea. Probably the most common approach to understanding inter-nation equity is to view it as a substitute for a general notion of fairness in how tax revenues are shared among states. In this sense, inter-nation equity is employed to provide certain normative legitimacy to the author's main claim but with no further elaboration on what it might mean as a normative guide. ${ }^{24}$

${ }^{19}$ Ruth Mason, Tax Expenditures and Global Labor Mobility, 84 N.Y.U. L. REV. 1540, 1593-99 (2009).

${ }^{20}$ Christopher Rose, Exchange of Tax Information: Neutrality and Inter-Nation Equity (2007) (unpublished $\mathrm{Ph} . \mathrm{D}$. thesis, University of Oxford) (on file with author).

${ }^{21}$ For additional examples of how inter-nation equity has been used (and misused) in the literature besides the ones listed above, see Brooks, supra note 5, at 489-90.

${ }^{22}$ Some may argue that inter-nation equity is insufficient as the sole guide for allocating taxing rights but still do not disagree that it deserves consideration as a factor. See Musgrave \& Musgrave, supra note 3 and accompanying text.

${ }^{23}$ See Kaufman, supra note 7, at 203 (arguing that a conception of inter-nation equity deserves greater attention than it has received); Diane Ring, Democracy, Sovereignty and Tax Competition: The Role of Tax Sovereignty in Shaping Tax Cooperation, 9 FLA. TAX REV. 555, 583 (2009) ("[F]irm foundations for a generally accepted vision of inter-nation equity have yet to be established ..."); Miranda Stewart \& Yariv Brauner, Introduction: Tax, Law and Development, in TAX LAW AND DEVElopment 3, 18 (Miranda Stewart \& Yariv Brauner eds., 2013) ("[A]lthough some have engaged with the concept of internation equity, it has remained rather thin and has not been particularly tractable to substantive analysis."). Besides the work of the Musgraves, rare exceptions include Kaufman, supra note 7; Brooks, supra note 5; Jinyan Li, Improving Inter-nation Equity through Territorial Taxation and Tax Sparing, in GloBAliZATION AND ITS TAX DisCONTENTS TAX POLICY AND INTERNATIONAL INVESTMENTS 117 (Arthur J. Cockfield ed., 2010); Anthony C. Infanti, Internation Equity and Human Development, in Tax Law and Development 209 (Miranda Stewart \& Yariv Brauner eds., 2013).

${ }^{24}$ Some of the recent literature includes, Carlo Garbarino, Inter-country Equity and Intra-group Transactions at EU Level: An Analysis of the CCCTB Proposal and ECJ Tax Cases, 21 E.C. TAX REV. 248 (2012); Reinout de Boer \& Otto Marres, BEPS Action 2: Neutralizing the Effects on Hybrid Mismatch Arrangements, 43 InTERTAX 14 (2015); Jan Szczepański, Personal Genuine Links under Domestic Inheritance Tax Rules in the Light of International and European Standards, 43 INTERTAX 595 (2015); Bastiaan Starink, Source versus Residence State Taxation of Cross-Border Pension Payments: Trouble Shared Is Trouble Halved, 44 InTERTAX 6 (2016); Bruno Peeters \& Herwig Verschueren, The Impact of European Union Law on the Interaction of Members States' Sovereign Powers in the Policy Fields of Social Protection and Personal Income Tax Benefits, 25 E.C. TAx REV. 262 (2016); Wolfgang Schön, One Answer to Why and How to Tax the Digitalized Economy, 47 InTERTAX 1003 (2019); Johannes Becker \& Joachim Englisch, Taxing Where Value Is Created: What's 'User Involvement' Got to Do with It?, 47 INTERTAX 161 (2019). 
A second recurring conception of inter-nation equity is to understand it as the normative basis for taxation at source. ${ }^{25}$ However, views differ on the extent to which source-based taxation is supported by inter-nation equity. Some argue that it requires greater taxing rights to source countries. ${ }^{26}$ Others take it to provide a much more limited support for taxation at source and suggest restricting its application to earnings with abovenormal rates of return. ${ }^{27}$ And some even take an absolutely opposite view by arguing that inter-nation equity leads to exclusive residence-based taxation. ${ }^{28}$

Inter-nation equity is also thought to provide normative grounds for how to allocate multinationals' profits among jurisdictions. However, whereas some argue that it supports a balanced consideration between the supply and demand sides of economic activity in allocating profits (that is, a supply-demand approach), ${ }^{29}$ others argue, conversely, that inter-nation equity requires a supply-only approach to profit allocation. ${ }^{30}$

A less prevalent view of inter-nation equity focuses on its appeal for international redistribution aimed at addressing the revenue concerns of lower-income countries. ${ }^{31}$ In this sense, some point out that inter-nation equity captures the belief that the global tax revenue pie is distributed unfairly with respect to developing nations and consequently supports a claim for global distributive justice. ${ }^{32}$ Similarly, some argue that inter-nation

${ }^{25}$ See, e.g., Alex Easson, Fiscal Degradation and the Inter-Nation Allocation of Tax Jurisdiction, 3 E.C. TAX REV. 112, 112-13 (1996) (arguing that inter-nation equity favors source-based taxation because capital-importing countries are usually poorer than capital-exporting countries); Michael P. Devereux \& Peter Birch Sørensen, The Corporate Income Tax: International Trends and Options for Fundamental Reform 17 (European Commission, Working Paper No. 264, 2006) (arguing that a source-based corporation tax is legitimate on the grounds of inter-nation equity since source countries provide costly infrastructure and protection of property rights that allow for profitable use of capital by foreign investors); Sijbren Cnossen, Company Taxes in the European Union: Criteria and Options for Reform, 17 Fiscal Studies 67, 79 n.22 (1996); Veronika Daurer, Tax Treaties and Developing Countries, 42 InTERTAX 695 (2014). See also Avi-Yonah, supra note 4, at 1648 (noting that inter-nation equity relates primarily to the question of entitlement and favors the prevalent practice of source-based taxation against the preference for residence-based taxation).

${ }^{26}$ See, e.g., Eyitayo-Oyesode, supra note 15 (arguing that inter-nation equity should prevent the current restrictions on source-based taxation in the OECD and the UN model tax treaties).

${ }^{27}$ See, e.g., Peter Birch Sörensen, Issues in the Theory of International Tax Coordination 14-15 (Bank of Finland, Working Paper No. 4/1990, 1990); Vincent C. Avagliano, The Second Wave: IT Outsourcing, Globalization, and Worker Rights, 23 PENN ST. InT'L. L. REV. 663, 684 (2005).

${ }^{28}$ William B. Barker, Optimal International Taxation and Tax Competition: Overcoming the Contradictions, 22 Nw. J. INT'L L. \& Bus. 161, 205 (2002) (arguing that inter-nation equity requires the assignment of the tax base exclusively to the residence state because that state provides the environment for the production and suffers a large loss in income and jobs due to the export of its capital and labor whereas the source state enjoys disproportionately greater benefits compared to what it provides).

${ }^{29}$ See, e.g., Erika Dayle Siu, Milly I. Nalukwago \& Marcos Aurélio Pereira Valadão, Lessons from Existing Subnational Unitary and Formulary Apportionment Approaches for a Regional Transition to Unitary Taxation, in TAXing Multinational EnTERPRises AS Unitary Firms 150, 169 (Sol Picciotto ed., 2017).

${ }^{30}$ See, e.g., Otto Jacobs, Christoph Spengel \& Anne Schäfer, ICT and International Corporate Taxation: Tax Attributes and Scope of Taxation, 31 INTERTAX 214, 231 (2003).

${ }^{31}$ See, e.g., Avi-Yonah, supra note 4, at 1650 (noting that inter-nation equity can be interpreted as embodying explicit redistributive goals so that "when a choice is presented between two otherwise comparable alternative rules, one of which has progressive and the other regressive implications for the division of the international tax base between poorer and richer countries, the progressive rule should be explicitly preferred to the regressive one.").

${ }^{32}$ Ring, supra note 23, at 585. Ring shows some skepticism towards this claim. As Part III.B will demonstrate, one of the reasons is that global justice claims at the time were mostly grounded on early cosmopolitanism. Recent discussions on global justice have gradually shifted toward a more refined, balanced view. See also Miranda Stewart, Redistribution between Rich and Poor Countries, 72 Bull. InT'L TAXATION 297 (2018) (taking inter-nation equity to mean that redistribution is warranted when international tax system leads to an unfair allocation of the international tax base). 
equity implies consideration for less affluent countries' interests. ${ }^{33}$ Others take inter-nation equity outside the context of tax jurisdiction allocation and understand it as a normative requirement for countries' commitment to aid low-income countries. ${ }^{34}$ Conversely, some have suggested that inter-nation equity equates to the principle of non-discrimination, thus translating to a notion of treating countries equally rather than benefiting lower-income states. ${ }^{35}$

Inter-nation equity has become the go-to concept when one needs to provide normative basis to a given stance on an international tax issue. ${ }^{36}$ Yet, when it comes to understanding what the concept entails, one finds that there are a significant number of competing conceptions. These conceptions capture only parts of what is a much more nuanced concept. Such a limited view of inter-nation equity hinders its potential as a normative guide for international tax policy and many times contradicts the main normative goal behind its original formulation. The following section will go over a few aspects of the Musgraves' original formulation and then offer one possible interpretation of the concept.

\section{The Musgraves' Original Formulation}

Peggy Musgrave articulated her conception of inter-nation equity throughout dozens of papers, in which she translated the concept into practical policy recommendations. ${ }^{37}$ She repeatedly noted that inter-nation equity does not apply exclusively to the distribution of tax jurisdictions. Rather, she argued that it more broadly relates to the overall economic gains and losses of the involved jurisdictions and that therefore consideration of any factors that impact a country's overall earnings, such as labor and capital, is warranted. However, acknowledging the complexity in analyzing these additional aspects, she frequently limited her analysis to what an equitable allocation of tax bases should be. ${ }^{38}$ Despite her extensive analyses and applications of the concept, inter-nation equity is most systematically articulated in the 1972 essay Inter-Nation Equity, ${ }^{39}$ co-authored with Richard Musgrave. In that paper, the Musgraves introduced inter-nation equity as a set of principles aimed to answer two fundamental questions: (1) which countries should tax income internationally and (2) how to distribute tax jurisdiction between them. ${ }^{40}$

${ }^{33}$ See, e.g., S.A. Stevens, The Duty of Countries and Enterprises to Pay Their Fair Share, 42 INTERTAX 702, 705-06 (2014); Martin Hearson, The Challenges for Developing Countries in International Tax Justice, 54 J. Develop. Stud. 1932 (2018).

${ }^{34}$ See, e.g., Neil Brooks \& Thaddeus Hwong, The Social Benefits and Economic Costs of TAXATION: A COMPARISON OF HIGH- AND LOW-TAX COUNTRIES 24-25 (2006).

${ }^{35}$ See, e.g., Maarten F. de Wilde, Some Thoughts on a Fair Allocation of Corporate Tax in a Globalizing Economy, 38 INTERTAX 281, 287 (2010).

${ }^{36}$ See Brooks, supra note 5, at 491 (noting that Musgrave and Musgrave's 1972 essay continues to be cited regularly decades after publication and the concept of inter-nation equity continues to be relevant as a widely accepted criterion for assessing the international tax regime).

${ }^{37}$ See sources cited supra note 9.

${ }^{38}$ See, e.g., Musgrave, Interjurisdictional Equity, supra note 9, at 54 ("In fact, the significance of these tax arrangements for [interjurisdictional equity] goes beyond the mere revenue share. As capital moves from one jurisdiction to another, this not only affects tax bases but also has its impact on factor earnings in both host and home jurisdictions. . At the same time, allowance for these secondary effects in determining an equitable distribution of tax bases would be administratively unmanageable, so, for practical purposes, [interjurisdictional equity] has to be confined to revenue shares.").

${ }^{39}$ Musgrave \& Musgrave, supra note 3.

${ }^{40}$ Musgrave's analysis is sophisticated in many respects and is not limited to these two normative principles. This article will not go into these details because the main goal is to understand the normative 
The first aspect of the Musgrave's conception of inter-nation equity, regarding the allocation of taxing rights, concerns the question of how to divide the international tax base among countries when a business residing in one country earns income in another country. Entitlement to tax is typically determined by the source principle, which allows a jurisdiction to tax foreign income generated within its territory, and the residence principle, which recognizes the right of a jurisdiction to tax all income of its residents regardless of where the income was earned. The Musgraves argue that the source principle should take precedence in determining entitlement to tax. In their view, there are two main reasons for this choice. First, because low-income countries are typically source jurisdictions, it would be inequitable to favor residence-based taxation. ${ }^{41}$ Second, because the place of corporate residence involves a fairly arbitrary decision by the corporation itself and can be easily manipulated. ${ }^{42}$

Once it is determined that the source country has the primary entitlement to tax, the next question is how much the source country is entitled to tax. ${ }^{43}$ Two assumptions made by the Musgraves are relevant here. The first assumption is that any income earned by an investor arising from international trade and investment is part of the residence country's earnings. This means that any taxes imposed at source will result in inter-nation redistribution (transfer of international gains from the residence to the source country), whereas any taxes imposed by the residence country will not (because it only transfers earnings from a resident to the treasury of the residence country). ${ }^{44}$ The rationale behind this assumption is not clear. One reason might be that until 1991, the United States used as its overall economic indicator the gross national product (GNP), which includes income earned by residents overseas and excludes income earned by non-residents in the country. In 1991, the United States shifted to gross domestic product (GDP), which computes exclusively income produced in the country, either by residents or non-residents. ${ }^{45}$ Another reason might be that the Musgraves adopted the typical assumption that income is owned by who produces it, regardless of its place of origin. ${ }^{46}$ But the practical

grounds for the principles they articulate and how these principles are situated in the current global justice debate.

${ }^{41}$ Musgrave \& Musgrave, supra note 3, at 78.

${ }^{42} I d$.

${ }^{43}$ The Musgraves highlight that inter-nation equity is relevant in determining the distributional claims not only between source and resident countries, but also among the different possible source countries and the different possible residence countries. As for the latter, they argue that a residence country should be entitled to tax only if it is either the country of source or the country of primary tax allegiance (residence or citizenship) for individual shareholders owning a substantial proportion of the equity. See Musgrave \& Musgrave, supra note 3, at 78-79.

${ }^{44}$ This assumption is later relaxed, when they consider that whenever the incidence of corporation tax falls on consumers rather than solely on profits, taxation by the residence country on its foreign investment results in a national loss to the source country (and a gain to the residence country). In such a case, they argue that residence-based taxation would be inappropriate for redistributive reasons because the capital exporting country will hardly be the low-income country. See id. at 80-81.

45 See United States Bureau of Economic Analysis, Gross Domestic Product as a Measure of U.S. PRODUCTION 8 (1991).

${ }^{46}$ Klaus Vogel criticized this assumption by arguing that it ignores the fact that when income is produced it consists of values integrated into the economy of the source country and thus is subject to that state's sovereignty. See Vogel, supra note 7, at 400-01. Kaufman also questions whether the Musgraves' assumption is still valid because of the universality of source-based taxation in today's international tax system. See Kaufman, supra note 7, at 194. Kaufman's criticism, however, seems to conflate entitlement to overall earnings (which is what Musgrave's assumption refers to) with entitlement to tax (which is what the source principles relates to). The main question here is about which country has the legal or moral right over gains arising from international trade and investment. The main problem with the Musgraves' assumption that the 
consequences of this assumption are significantly attenuated by their preference for the source principle for allocating tax jurisdiction, thus giving the source country the primary entitlement to tax.

The second assumption made by the Musgraves is a corollary to the first. Taxation by the residence country affects inter-individual equity in that country but does not interfere with inter-nation equity. Therefore, in their view, inter-nation equity is exclusively determined by how much tax jurisdiction is allocated to the source country. The tax rate applied at the source will determine how much international gain is transferred from the residence country to the source country and thus determine how taxing rights are divided between the residence country and the source country. Therefore, determination of the appropriate tax rate applicable at the source is an important factor for inter-nation equity. The Musgraves propose three alternative principles for making such a determination: the principle of non-discrimination, the principle of national rental, and the distributional approach.

The first possible criterion for determining the tax rate at source is the principle of non-discrimination, which follows what they take to be "the general principle of equality under the law" and requires that "all economic activity within a country's border be treated alike." ${ }^{\prime 7}$ The practical implication is that source countries' withholding tax rates should vary according to their own rate structure so that the same combined tax rate is imposed on domestic and foreign taxpayers.

The principle of national rental considers the total national gains of each country (residence and source) accruing from international investment ${ }^{48}$ and suggests that there should be some form of equal net benefit to both sides. According to this principle, if the source country is resource-rich but capital-poor, it should be allowed to charge a national rental charge for the use of its investment environment and natural resources. ${ }^{49}$

The distributional approach builds on the national rental principle, but unlike that principle, the rates adopted by each source country vary according to "distributional considerations." ${ }^{\circ 0}$ Under this approach, rather than a reciprocal or equal rate schedule, tax rates at source should be differentiated so that they would relate inversely to per capita income in the source country and directly to per capita income in the residence country, so as to improve the relative position of low-income countries. ${ }^{51}$ For instance, if the source country has a low GDP per capita in relation to the residence country's GDP per capita, the allowable tax rate at source will be significantly high. If the source country's GDP per capita is low relatively to the residence country's GDP per capita, the allowable tax rate will be proportionately lower. ${ }^{52}$ The main underpinning for the distributional approach is

residence country holds primary entitlement over gains from international investment is that the issue might require a more in-depth discussion over international property rights that are not explicitly addressed.

${ }^{47} \mathrm{Id}$. at 72 .

48 This includes the net gain to the residence country due to increased capital income and the net gain to the source country due to increased labor income.

${ }^{49} \mathrm{Id}$. at $72-74$.

${ }^{50}$ The Musgraves describe it as rental rates tempered by distributional considerations.

${ }^{51} \mathrm{Id}$. at 74.

52 The Musgraves provide the following table as an example of what the distributional approach would look like. Id. 
the normative demand to promote international redistribution in a world with a "highly unequal distribution of resource endowments and per capita income among countries and in the absence of an adequate method for dealing with the problem". ${ }^{53}$

The Musgraves note that these principles are incompatible with each other, so that a choice must be made as to which principle applies in each case. ${ }^{54}$ The choice, in their view, depends fundamentally on whether the residence and the source countries are at the same or different levels of development. When both are high-income countries, either the non-discrimination or the national rental principle could apply. However, in treaty arrangements between low-income and high-income countries, the distributional approach takes priority. ${ }^{55}$ This two-pronged standard for allocating taxing rights among jurisdictions points to a dual notion of inter-nation equity. Part III will explore a few normative implications of this view.

III. INTER-NATION EQUITY AS A TWO-FOLD CONCEPT

\section{A. Two Normative Components}

As shown above, most conceptions of inter-nation equity tend to incorporate only some aspects of the concept originally formulated by the Musgraves. These conceptions usually fail to recognize the importance of the Musgraves' assertion of a two-pronged approach to allocating rights that considers, on the one hand, economic imputation and, on the other hand, international redistribution. ${ }^{56}$

For this discussion, it is helpful to consider two alternative normative approaches for allocating tax jurisdiction at an international level. Entitlement approaches consider a jurisdiction entitled to tax by virtue of a specific political or economic relationship with the person or income being taxed. From a moral perspective, this approach relies on the notion of tax sovereignty and builds on a statist view of international relations. ${ }^{57}$ Discussions around source and residence are fundamentally informed by entitlement approaches. ${ }^{58}$ Differential approaches tend to disregard direct economic and political connections

\begin{tabular}{|c|c|c|c|c|}
\hline \multirow{3}{*}{$\begin{array}{l}\text { Per capita income } \\
\text { of capital-importing } \\
\text { country }(\$)\end{array}$} & \multicolumn{4}{|c|}{$\begin{array}{l}\text { Per capita income of capital-exporting } \\
\text { country }(\$)\end{array}$} \\
\hline & $\begin{array}{l}\text { below } \\
250\end{array}$ & $250-500$ & $500-1000$ & $1000+$ \\
\hline & \multicolumn{4}{|c|}{ Tax rates (per cent) } \\
\hline $\begin{array}{l}\text { Below 250 } \\
250-500 \\
500-1000 \\
1000+\end{array}$ & $\begin{array}{l}40 \\
30 \\
20 \\
10\end{array}$ & $\begin{array}{l}50 \\
40 \\
30 \\
20\end{array}$ & $\begin{array}{l}55 \\
45 \\
35 \\
25\end{array}$ & $\begin{array}{l}60 \\
50 \\
40 \\
30\end{array}$ \\
\hline
\end{tabular}
equal tax rates on income accruing to non-resident corporations. They point out that the principle has little economic justification and is incompatible with the more sensible principles they propose, namely the principle of non-discrimination, the national rental principle, and the distributional approach. See id.

${ }^{56} \mathrm{Id}$. at 85 ("On the whole, it would seem desirable to implement redistributional objectives through rate differentiation while attempting to divide the source in line with 'true' economic imputation.").

${ }^{57}$ Laurens van Apeldoorn, who calls this view an internationalist position, has accurately described it as the "model [that] conceives of states as independent and autonomous, entitled to shape their social, political and economic institutions as they see fit ... [S]tates are presumed to have an unqualified right to the resources they control and the wealth they create in their territory." Laurens van Apeldoorn, Exploitation, International Taxation, and Global Justice, 77 REV. Soc. ECON. 163, 167 (2019).

${ }^{58}$ For a broader analysis of this view, see Ivan Ozai, Origin and Differentiation in International Income Allocation, 44 DALHOUSIE L.J. (forthcoming 2021) (using the term origin-based approaches to refer to normative theories that build on the entitlement view). 
between a taxpayer and a state as morally relevant criteria to divide the tax base among countries. According to this view, tax jurisdiction should be distributed so as to carry out a universal moral objective, usually one that aligns with a concern about global justice. ${ }^{59}$ Differential approaches take the allocation of taxing rights as a significant tool for addressing global inequality and propose a distribution among countries according to characteristics such as per capita income or number of inhabitants. Proposals for global taxes typically endorse this view. One prominent example is Thomas Pogge's global resources dividend (GRD). GRD is effectively a tax on the use of natural resources. The revenue collected would be distributed to less affluent countries. ${ }^{60}$ A recent proposal by a group of European tax professors to transfer to the European Union the power to levy specific taxes embraces both concepts simultaneously. ${ }^{61}$ Such a proposal does not entirely abandon the entitlement approach and possibly creates a regionally differential system.

The Musgraves seem to embrace neither of these approaches completely. They rather advance an allocation of tax jurisdiction based on "economic imputation" that is "tempered ... by distributional considerations," ${ }^{2}$ which indicates a two-fold view that combines an entitlement component — based on the notions of economic allegiance, ${ }^{63}$ benefit terms, ${ }^{64}$ and tax sovereignty ${ }^{65}$ — with a differential one. ${ }^{66}$

The entitlement component of inter-nation equity is grounded in the idea of sovereignty and is conveyed through the general alignment with the benefit principle, which requires an entitlement to tax according to the benefits derived from each country's provision of public goods and services. The Musgraves embrace source-based taxation by arguing that "a sovereign country is entitled to tax all activity which occurs within its borders." ${ }^{67}$ They also embrace residence-based taxation, but only as a normatively residual right over the entitlement of the source country. ${ }^{68}$ The principles of non-discrimination and of national rental are two corollaries of this normative component. As Part II.B has

${ }^{59}$ Alexander Cappelen calls this the assignment approach. See Alexander W. Cappelen, The Moral Rationale for International Fiscal Law, 15 ETHICS \& INT'L AFF. 97, 108 (2001) (“A characteristic feature of international fiscal law is that considerations of international income distribution do not have any role in the distribution of tax rights. The assignment approach would challenge this feature of international fiscal law based on what we could call the distributional objection. In its general version this objection points out that benefits arising from special relationships might work to the disadvantage of those who are most in need.").

${ }^{60}$ Thomas W. Pogge, Eradicating Systemic Poverty: Brief for a Global Resources Dividend, 2 J. Hum. Dev. 59, 67-68 (2007) ("Proceeds from the GRD are to be used toward ensuring that all human beings will be able to meet their own basic needs with dignity.").

${ }^{61}$ Frans Vanistendael et al., European Solidarity Requires EU Taxes, 98 TAX Notes INT'L 577 (May 4, 2020).

${ }^{62}$ Musgrave \& Musgrave, supra note 3, at 78.

${ }^{63}$ Musgrave, Combining, supra note 9, at 168.

${ }^{64} \mathrm{Id}$. at $172-73$.

${ }^{65}$ Musgrave \& Musgrave, supra note 3, at 71-72.

${ }^{66} \mathrm{Id}$. at $74-75,80,89$.

${ }^{67} \mathrm{Id}$. at $71-72$.

${ }^{68}$ In later work, Peggy Musgrave takes a more nuanced view of the residence country's entitlement to tax. She provides a basis for residence entitlement as a matter of tax sovereignty (because residents owe tax allegiance to their country of residence in return for rights and privileges they receive), as a requirement of inter-individual equity (by ensuring equitable tax treatment of resident taxpayers by taxing all their income wherever earned), and as corollary of the benefit principle (since the residence country provide productivityenhancing benefits to residents' factors of production prior to foreign investment as well as rights and privileges resulting from registration). See Musgrave, Combining, supra note 9, at 168-69. But she still regards the residence country as a residual taxing authority vis-à-vis the source country. $I d$. 
shown, this is markedly the most prevalent interpretation of inter-nation equity in the tax literature.

The differential component is an equally important but significantly overlooked aspect of the Musgraves' conception of inter-nation equity. ${ }^{69}$ The idea that international taxation should be informed by a moral requirement of redistribution from high- to lowincome countries run through many of the policy recommendations offered in their 1972 essay. Along with the case they made for a differentiated tax rate schedule based on each country's different level of per capita income, ${ }^{70}$ the Musgraves also took distributional considerations into account when they argued for an internationally agreed-upon framework to replace the existing bilateral treaty network, ${ }^{71}$ against taxation at residence whenever the corporation tax incidence falls on consumers, ${ }^{72}$ for primary source-based taxation, ${ }^{73}$ and when considering an apportionment formula for allocating the international tax base among multiple source countries. ${ }^{74}$ In later work, Peggy Musgrave also referred to distributional considerations when calling for investment in low-income countries, ${ }^{75}$ condemning tax competition, ${ }^{76}$ and arguing against the unilateral substitution of consumption taxes for the income tax by the United States ${ }^{77}$ and compensatory revenue transfers in case of global substitution of consumption taxation. ${ }^{78}$

Despite the ubiquitous concern with distributional considerations in the Musgraves' (notably in Peggy Musgrave's) scholarship,$^{79}$ it would be misleading to take their case for international redistribution as a call for cosmopolitan global justice. ${ }^{80}$ Global cosmopolitanism typically disregards the significance of states and treats each individual as a member of a universal society and thus deserving of an equal share of entitlements. ${ }^{81}$ Although the differential component is an important part of the Musgraves' conception of inter-nation equity, they still consider the entitlement component to be a fundamental component of the concept. As the following section will discuss, this normative position aligns with what could be regarded in today's global justice debate as a middle course between cosmopolitanism and statism. ${ }^{82}$ That the Musgraves took such an unorthodox

${ }^{69}$ See Kaufman, supra note 7, at 203 (pointing out that it would be a mistake to disregard the differential aspect of the Musgraves' scholarship and think of inter-nation equity only in terms of entitlement theory).

${ }^{70}$ Supra note 50. The idea for a tax rate schedule inversely related to per capita income was reiterated in Musgrave, Interjurisdictional Equity, supra note 9, at 59.

${ }^{71}$ Musgrave \& Musgrave, supra note 3, at 79-80.

${ }^{72} \mathrm{Id}$. at 80 .

${ }^{73} \mathrm{Id}$. at 78 .

${ }^{74} \mathrm{Id}$. at 85 .

${ }^{75}$ Musgrave, Combining, supra note 9, at 170.

${ }^{76}$ Musgrave, Sovereignty, supra note 9, at 1343-44; Musgrave, Taxing, supra note 9, at 1478.

${ }^{77}$ Musgrave, Sovereignty, supra note 9, at 1353-54.

${ }^{78} \mathrm{Id}$. at 1355.

${ }^{79}$ But see Infanti, supra note 23, at 214 (noting that although Peggy Musgrave often revisited her articulation of inter-nation equity in later work, she never returned to its differential aspect in a similarly sustained way).

${ }^{80}$ This seems to be the position taken, for example, by Avi-Yonah, supra note 4, at 1648-49.

${ }^{81}$ Cosmopolitanism and other views on the global justice debate will be further discussed in Part

III.B.

82 See Laura Valentini, Justice in a Globalized World: A Normative Framework 3-4 (2011). Peggy Musgrave's adoption of a moderate view on global justice is also indicated by the fact that her scholarship is significantly informed by the concept of inter-individual equity (within a state) as a normative requirement that is separate from inter-nation equity. 
position in their 1972 essay at a time when discussions about global justice were still incipient is but one facet of the ingenuity of their scholarship.

\section{B. Normative Compromise}

One of the questions regarding what constitutes global justice asks whether principles of distributive justice should be constrained to the domestic realm or whether they should extend to the international domain as well. On one end of the spectrum of answers to this question stands global cosmopolitanism, which argues that normative requirements of distributive justice should apply at the global level. ${ }^{83}$ Global cosmopolitan theories are rich and nuanced, and they increasingly vary in content, scope, and justification. ${ }^{84}$ But all cosmopolitan theorists share the belief that human beings-and not families, cultures, or nations - are the ultimate units of moral concern and thereby should be treated equally regardless of nationality or citizenship. ${ }^{85}$ On the other end stands statism, which typically claims that no duty of egalitarian distributive justice exists outside of the state. ${ }^{86}$ Statists usually accept that we have universal duties to provide humanitarian assistance to those in desperate need, but these duties are limited and not grounded on principles of distributive justice. ${ }^{87}$

Between these two normative accounts of global justice, several recent theories have positioned themselves somewhere in the middle of the spectrum. Some have called this a "third wave" of the debate on global justice. ${ }^{88}$ This middle course position generally rejects theories that accept no principles of justice at the global level as well as theories

${ }^{83}$ Early works embracing global cosmopolitanism are CHARLES BeITZ, PolitiCAL THEORY AND International Relations (1973) and Thomas W Pogge, Realizing RaWls (1989). For more recent theories of global cosmopolitanism, see Darrel Moellendorf, Cosmopolitan Justice (2002); KoK-Chor Tan,

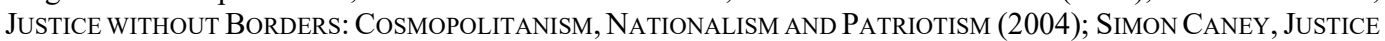
BEyOnd Borders: A Global Political TheOry (2005).

${ }^{84}$ One fundamental distinction is offered by Andrea Sangiovanni. See Andrea Sangiovanni, Global Justice, Reciprocity, and the State, 35 PHIL. \& PuB. AfF. 3 (2007). He divides cosmopolitan theories into relational and non-relation conceptions of distributive justice. In non-relational cosmopolitanism, duties of justice should extend beyond national borders because they rest on a conception of person rather than of the existence of particular types of social relations or institutions. Conversely, relational cosmopolitanism conditions the extension of principles of distributive justice to the international realm to the existence of shared political, social or cultural shared values or institutions. Relational cosmopolitanism theorists typically argue that there exists a global basic structure which requires that liberties, opportunities and wealth be equally distributed across the world.

${ }^{85}$ Kok-Chor Tan, The Demands of Global Justice, 3-4 OECONOMIA 665 (2013). See also Sangiovanni, supra note 84 , at 3.

${ }^{86}$ One important representative of this view is Thomas Nagel, The Problem of Global Justice, 33 PhIL. \& PuB. AfF. 113 (2005). Frequently deemed representatives of a moderate statist view include Michael Blake, Distributive Justice, State Coercion, and Autonomy, 30 Phil. \& Pub. Aff. 257 (2001); Samuel Freeman, The Law of Peoples, Social Cooperation, Human Rights, and Distributive Justice, 23 Soc. PHIL. \& Pol'y 29 (2006). For a discussion about the statist view applied to international tax policy, see Laurens van Apeldoorn, A Sceptic's Guide to Justice in International Tax Policy, 32 CAN. J.L. \& JURIS. 499 (2019).

87 This normative concession was taken by many critics as inadequate to addressing global economic injustice. See, e.g., Thomas Pogge, 'Assisting' the Global Poor, in The Ethics of Assistance: Morality AND THE Distant NeEdy 260 (Deen K Chatterjee ed., 2004). Pogge differentiates duties of assistance from duties of distributive justice mainly because the former has an absolute target whereas the latter has a relative target that constrains international inequalities. Id. at 261.

${ }^{88}$ In Laura Valentini's reading, this "third wave" provides "a sustained critical discussion of cosmopolitanism and statism, and a fresh perspective helping us to steer a middle course between them." VALENTINI, supra note 82, at 3. According to Valentini, two representatives of this position are GILLIAN Brock, Global Justice: A Cosmopolitan Account (2009) and David Miller, National Responsibility AND GloBAL Justice (2007). Yet, as she notes, these authors explicitly place themselves in the cosmopolitan and statist traditions, respectively. 
that claim that the same principles apply both domestically and globally. Intermediary positions on global justice generally agree with cosmopolitans that duties of justice exist in the realm of global distribution, while agreeing with statists that the state has a special place in accounts of justice, so that duties of justice applied internationally differ in content and scope to those applied domestically. ${ }^{89}$

This middle course position is sometimes referred to as "internationalism." The term is fitting, as it conveys the idea that the scope of principles of distributive justice extends not only outside but also between ("inter") states. ${ }^{90}$ Because there is currently no substitute for the state as a political mechanism for realizing people's democratic preferences, global distributive justice is to be achieved through states rather than beyond them. A normative compromise that includes both an entitlement component (that recognizes state sovereignty) and a differential one (that allows for the demands of global distributive justice) should require that international regimes and institutions allocate both political and economic rights to jurisdictions in a way that do not worsen global inequality and, to some degree, promote global justice. How and to what extent the differential component applies will be further explored in Part IV.

\section{The Concept of Differentiation}

The dual conception of inter-nation equity introduced in Part III.A prominently aligns with the internationalist stance of global justice advanced in Part III.B. It demands the integration of two apparently opposing normative requirements: that states are entitled to the wealth generated in their territories or arising from the resources they control and that the distribution of rights over that wealth should allow for a differential regime that favors less affluent economies. ${ }^{91}$

Although the differential approach is still quite unorthodox in the international tax law context, it has been applied to some degree to foster substantive equality among states with varying levels of capacity in areas of international labor law, ${ }^{92}$ law of the sea, ${ }^{93}$ international trade law, ${ }^{94}$ international climate law, ${ }^{95}$ and international patent law. ${ }^{96}$

One of the fundamental tenets of international law is the principle of sovereign equality, which conveys the notion of equal rights and strict reciprocity between states. ${ }^{97}$ Sovereign equality is limited to recognizing states' sovereignty and implies formal equality

${ }^{89}$ See, e.g., Jon Mandle, Global Justice (2006); Sebatiano Maffettone, Global Justice: Between Leviathan and Cosmopolis, 3 Global Pol'y 443 (2012); Mathias Risse, On Global Justice (2012).

${ }^{90}$ RisSE, supra note 89 , at 10.

${ }^{91}$ Laurens van Apeldoorn, although adopting different normative assumptions and a different scope, has recently made a similar case for restricting the entitlement approach to promote some degree of international redistribution. See Laurens van Apeldoorn, International Tax Co-operation in an Unjust World: Do States Have an Entitlement to Tax Income Arising in Their Territory?, 4 BRIT. TAX REV. 557, 558 (2019) ("[R] elatively affluent states have an exclusive (or primary) entitlement to tax income arising in their territory only in the absence of subsistence rights deficits abroad (in so far as such deficits can be prevented by curtailing that entitlement).").

92 Constitution of the International Labour Organization (ILO) art. 19(3).

${ }^{93}$ United Nations Convention on the Law of the Sea art. 61-62, Dec. 10, 1982, 1833 U.N.T.S. 397.

${ }^{94}$ General Agreement on Tariffs and Trade art. XVIII, Oct. 30, 1947, 61 Stat. Pt. 5, 55 U.N.T.S 194

${ }^{95}$ United Nations Framework Convention on Climate Change art 3, May 91992 S. Treaty Doc No. 102-38, 1771 U.N.T.S. 107 [hereinafter UNFCC].

${ }^{96}$ Agreement on Trade-Related Aspects of Intellectual Property Rights art. 65(2), 65(4), 66(2), and 67, Jan. 1, 1995, 1869 U.N.T.S. 299.

${ }^{97}$ Brad R. Roth, Sovereign Equality and Moral Disagreement 55 (2011). Sovereign equality is codified in U.N. Charter art. 2(1): "The Organization is based on the principle of the sovereign equality of all its Members." 
between states, despite economic, political, and military inequalities. ${ }^{98}$ Differential treatment is a deviation from the principle of sovereign equality. ${ }^{99}$ It typically consists of non-reciprocal arrangements aimed at promoting substantive equality between countries. ${ }^{100}$ The rationale for differentiation in international law lies in the recognition that formally equal treatment can secure equality only among parties at an identical or similar level of economic and political power, and that differentiated treatment is necessary to correct inequalities among parties without similar economic or political attributes. ${ }^{101}$ Differentiation is also seen as a way to foster international cooperation and facilitate the effective implementation of international norms. ${ }^{102}$

One prominent example of differential treatment is the principle of common but differentiated responsibilities and respective capabilities, formalized in the United Nations Framework Convention on Climate Change. ${ }^{103}$ This principle distinguishes between countries according to their level of responsibility for greenhouse gas emissions and their varying capacities to act in response. It not only guides differentiated obligations under the UN's climate change convention, but also has specific applications in particular areas of activity, such as adaptation, technology transfer, finance and capacity building, and allows for other tailored interpretations by negotiating groups. ${ }^{104}$

The principle of common but differentiated responsibilities and respective capabilities allocates greater environmental burdens and costs to affluent countries than to poor ones. The rationale derives from both distributive justice and a form of restorative justice. The former holds that distribution of burdens should be made according to countries' ability to pay to avoid delaying poverty eradication in less developed

${ }^{98}$ Lora Anne Viola, Duncan Snidal \& Michael Zürn, Sovereign (In)Equality in the Evolution of the International System, in THE OXFORD HANDBOOK OF TRANSFORMATIONS OF THE STATE 221, 223-24 (Stephan Leibfried et al. eds., 2015) ("Traditional theorizing on international relations takes state relations to be characterized by resource inequality on the one hand, and sovereign equality on the other hand. ... As a principle of the international system, sovereign equality emphasizes the equality of states in spite of obvious resource inequalities.").

${ }^{99}$ Philippe Cullet, Differential Treatment in International Law: Towards a New Paradigm of Interstate Relations, 10 E.J.I.L. 549, 551 (1999).

${ }^{100}$ Differential treatment recognizes the limits of a system based on the fiction of legal equality between states that imposes reciprocity of commitments by all state parties to any treaty. See Daniel Barstow Magraw, Legal Treatment of Developing Countries: Differential, Contextual, and Absolute Norms, 1 Colo. J. INT'L ENVTL. L. \& POL'Y 69 (1990). For a discussion about rules that are nominally reciprocal but substantively asymmetrical in international taxation, see Steven A. Dean, More Cooperation, Less Uniformity: Tax Deharmonization and the Future of the International Tax Regime, 84 TUL. L. REV. 125 (2009).

${ }^{101}$ See Oscar Schachter, The Evolving Law of International Development, 15 COLUM. J. TRANSNAT'L L. 1 (1976) (grounding differential treatment on a consideration of need as basis for entitlement); Cullet, supra note 99, at 550; Frank J. Garcia, Trade, Inequality, and Justice: Toward a Liberal Theory of Just TRADE (2003) (taking differentiation as a mechanism to achieve wealth redistribution in the face of substantial inequalities); Eduardo Tempone, Special and Differential Treatment, MAX PlanCK ENCYClOPEDIA OF PuBLIC INTERNATIONAL LAW (Dec. 10, 2020), https://opil.ouplaw.com/view/10.1093/law:epil/9780199231690/law9780199231690-e2159?rskey=Ra4rSo\&result=2\&prd=MPIL [https://perma.cc/K63S-87G3].

102 Cullet, supra note 99; Tempone, supra note 101.

${ }^{103}$ UNFCC, supra note 95, art. 3(1).

104 Sébastien Jodoin \& Sarah Mason-Case, What Difference Does CBDR Make? A Socio-Legal Analysis of the Role of Differentiation in the Transnational Legal Process for REDD+, 5 TRANSNAT'L ENVIRON. L. 255, 257 (2016). 
countries. ${ }^{105}$ The latter holds that the distribution of burdens should consider countries' historical contribution to climate change as a measure of their responsibility. ${ }^{106}$

When it comes to the international tax system, similar normative grounds call for differentiation. ${ }^{107}$ From a historical point of view, some of the fundamental problems of the international tax regime affecting the current distribution of taxing rights such as tax competition and tax avoidance significantly result from how the present rules were designed in the 1920s, when the League of Nations commissioned a group of experts to evaluate how to avoid the problem of double taxation in cross-border transactions. ${ }^{108}$ The decisions made then by today's most powerful economies resulted in the current web of inconsistent rules that are increasingly exploited by multinationals to avoid taxes. ${ }^{109}$ Lowincome economies have often times been encouraged by wealthier countries and by international organizations such as the IMF or the World Bank to pursue policies that include low taxation of capital. ${ }^{110}$ Moreover, policy choices made by developed countries in the last few decades have intensified tax competition. The adoption of specific domestic policies of developed countries has created international conditions that favored tax competition over cooperation, constraining policy alternatives of less developed countries, as multinationals put pressure on them to reduce their taxes. ${ }^{111}$

105 Darrel Moellendorf, The Moral Challenge of Dangerous Climate. Change: Values, POVERTY, AND POLICY 173-77 (2014).

${ }^{106}$ Henry Shue, Global Environment and International Inequality, 75 INT'L AfF. 531 (1999); Simon Caney, Climate Change and the Duties of the Advantaged, 13 CRIT. REv. InT'L Soc. \& Pol. PHIL. 203 (2010).

${ }^{107}$ For an exploration of how a similar principle could apply to reform proposals aimed at addressing tax competition, see Ivan Ozai, Tax Competition and the Ethics of Burden Sharing, 42 FordHAM InT'L L.J. 61 (2018).

108 See Allison Christians, BEPS and the Power to Tax, in TAX SOVEREIGNTY IN THE BEPS ERA $§ 1$ (Sérgio André Rocha \& Allison Christians eds., 2016).

109 Policymakers at the time did foresee that this tax regime would allow taxpayers to more easily engage in tax avoidance and evasion, but they were more concerned that an alternative solution would harm efforts to liberalize trade and investment, the primary objective at the time. See Thomas Rixen, From Double Tax Avoidance to Tax Competition: Explaining the Institutional Trajectory of International Tax Governance, 18 ReV. INT'L POL. ECON. 197, 212 (2011).

110 Philipp Genschel \& Laura Seelkopf, Winners and Losers of Tax Competition, in GLOBAL TAX Governance: What Is Wrong With IT AND How to Fix It 55, 69 (Peter Dietsch \& Thomas Rixen eds., 2016) (pointing out that international organizations such as the United Nations Conference on Trade and Development (UNCTAD) often encourage small, resource-poor countries to embrace tax-haven strategies as a means for accelerating development). An important point to make is that the current tax regimes of many tax havens is not the expression of their political will as they are "often holdovers from the colonial era." Steven A. Dean, Philosopher Kings and International Tax: A New Approach to Tax Havens, Tax Flight, and International Tax Cooperation, 58 HASTINGS L.J. 911, 936 (2007).

${ }^{111}$ See Allison Christians, Global Trends and Constraints on Tax Policy in the Least Developed Countries, 42 U.B.C. L. REv. 239, 265-66 (2010) (pointing to the United States' international tax rules as an example of policies that increase the sensitivity of taxpayers to foreign tax rates); Karen B. Brown, Introduction, in TAXation And Development: A Comparative Study XV, XV (Karen B. Brown ed., 2017) (" $[\mathrm{P}]$ olicies instituted by the leaders of the more industrialized, higher-income nations in their quest to produce and prosper helped to create the environmental degradation plaguing everyone, particularly nations which are geographically and economically vulnerable."). See also Peter Dietsch, Catching Capital: The Ethics of Tax Competition 44-46 (2015). Some have noted that given the need for tax revenues, developing countries would generally prefer not to engage in tax competition, but they are compelled to grant tax incentives in response to the existing competitive scene. See, e.g., Reuven Avi-Yonah, Globalization and Tax Competition: Implications for Developing Countries, 44 L. QuADRANGLE Notes 60, 63 (2001). 
From a broader perspective, economic globalization is at least a partial factor that contributes to global poverty. ${ }^{112}$ This causal relationship implies that some degree of correction is warranted to reduce or eliminate inequalities stemming from global factors. ${ }^{113}$ While globalization of markets has allowed rapid growth for some economies, it has left many others lagging behind in living standards. ${ }^{114}$

From a distributive justice standpoint, the international tax regime increasingly constitutes a strong and largely non-voluntary economic association between countries. This raises special associative duties - duties owed to parties with whom one stands in a robust relationship or interaction ${ }^{115}$ —one of which is the duty of international institutions not to become sources of privileges to wealthier, more powerful participants. ${ }^{116}$ More broadly, the current level of economic integration of nations has made the global economy a substantial presence in the lives of all states, and economic regulation and policy decisions today take place in a global setting that is inescapably interdependent. The fact that rules made by a state (or by supranational rule-making bodies) are consequential to other states raises the need for some degree of coordination and equity beyond the national level. ${ }^{117}$

\section{ALLOCATING RIGHTS ACCORDING TO INTER-NATION EQUITY}

A. Reconciling Entitlement and Differentiation

Part III introduced the dual conception of inter-nation equity by showing that, from a normative perspective, it builds on an internationalist view of global justice and, from a legal perspective, it can operate through the mechanism of interjurisdictional differentiation. Once the dual conception of inter-nation equity is established as a normative guide for allocating taxing rights, the question that follows is how to reconcile inter-nation equity's two normative components. When should the allocation of taxing rights be guided by an entitlement approach, thus preserving allocation on the basis of sovereignty and economic allegiance, and when should it give way to a differential approach, thereby tackling global inequality)?

112 This view is sometimes called "explanatory pluralism" and rejects that global poverty can be wholly explained as either a product of domestic factors (explanatory nationalism) or a result of global factors (explanatory globalism). See Chris Armstrong, Defending the Duty of Assistance?, 35 Soc. THEORY \& PrAC. 461, 468-69 (2009).

113 Building on luck egalitarianism, Cappelen argues for what he calls a principle of equalization at the international level, according to which the opportunities different countries have to pursue their goals be equalized, so that differences stemming from global factors be eliminated. See Alexander Cappelen, Responsibility and International Distributive Justice, in REAL WorLd Justice: Grounds, PrinciPLES, HuMAN Rights, And Social Institutions 215 (Andreas Follesdal \& Thomas Pogge eds., 2005). See also MAndLE, supra note 87, at 102 (arguing that this duty of justice is stronger among wealthy states and those that played a historical role in making the social order unjust such as through colonialism).

${ }^{114}$ Ilan Benshalom, How to Redistribute: A Critical Examination of Mechanisms to Promote Global Wealth Redistribution, 64 U. TOROnTO L.J. 317, 322 (2014). See generally JosePh E. Stiglitz, Making GLOBALIZATION WORK 100 (2006).

115 These duties are sometimes called relational duties. See Andrea Sangiovanni, On the Relation Between Moral and Distributive Equality, in Cosmopolitanism Versus Non-COSMOPOLITANISM: CRITIQUES, DEFENSES, RECONCEPTUALIZATIONS 55 (Gillian Brock ed., 2013).

${ }^{116}$ Darrel Moellendorf, Cosmopolitanism and Compatriot Duties, 94 Monist 535 (2011). See also Darrel Moellendorf, Human Dignity, Associative Duties, and Egalitarian Global Justice, in CoSMOPOLITANISM Versus Non-Cosmopolitanism: Critiques, Defenses, ReConceptualizations 222 (Gillian Brock ed., 2013).

${ }^{117}$ Joshua Cohen \& Charles Sabel, Extra Rempublicam Nulla Justitia?, 34 PHIL. \& PuB. AfF. 147, 165 (2006). 
A solution to reconcile entitlement and differentiation might arise from the limitations of an entitlement approach as a sole normative guide to the allocation of taxing rights. A largely uncontested feature of the current tax rules for determining entitlement to tax is its significant arbitrariness. The concept of residence, for instance, particularly when applied to corporations, is significantly problematic. ${ }^{118}$ In contrast to an individual's residence, which is in part determined by the physical presence of that individual in a country, the place of a corporation's residence is subject to a high degree of legal discretion and is significantly inconsistent throughout different tax systems. ${ }^{119}$ Despite being a foundational legal construct in international taxation, ${ }^{120}$ the concept of corporate tax residence is commonly regarded as "outdated and unstable," 121 incoherent, ${ }^{122}$ completely artificial, ${ }^{123}$ a "crude, if not naive, criterion," ${ }^{124}$ lacking economic substance, ${ }^{125}$ and not very meaningful. ${ }^{126}$ Some have gone farther and called for the abandonment of the concept altogether. ${ }^{127}$ As a result of this arbitrariness, multinational enterprises are able to easily adopt foreign statehood while governments cannot do much more than complain about the abuse of corporate residence for tax-avoidance purposes. ${ }^{128}$

Establishing a coherent concept of source appears to be an even more challenging task. Countries establish different sets of criteria to define the concept of source. ${ }^{129}$ Moreover, somewhat arbitrary thresholds, such as the permanent establishment requirement, are used to limit the taxation of non-residents at the source. ${ }^{130}$ The allocation

${ }^{118}$ See Tsilly Dagan, The Future of Corporate Residency (Sep. 29, 2017) (unpublished manuscript), https://papers.ssrn.com/sol3/papers.cfm?abstract_id=3045134 [https://perma.cc/8YEW-EHYX].

${ }^{119}$ See, e.g., Brian J. Arnold, A Tax Policy Perspective on Corporate Residence, 51 CAN. TAX J. $1559,1559-60$ (2003). For an extended analysis of the varying criteria employed by different jurisdictions to determine corporate residence, see ROBERT COUZIN, CORPORATE RESIDENCE AND INTERNATIONAL TAXATION (2002). Assigning tax residence to individuals, however, is without problems. For a comparative overview, see Reuven S. Avi-Yonah, Nicola Sartori \& Omri Marian, Global Perspectives on Income Taxation LAW 152-53 (2011).

120 Omri Marian, Jurisdiction to Tax Corporations, 54 B.C. L. REv. 1613 (2013).

${ }^{121}$ See, e.g., Graetz, supra note 7, at 1422.

122 See, e.g., Michael J. McIntyre, Determining the Residence of Members of a Corporate Group, 51 CAN. TAX J. 1567, 1568 (2003).

${ }^{123}$ See, e.g., Edward D. Kleinbard, The Lessons of Stateless Income, 65 TAx L. REV. 99, 159 (2011).

${ }^{124}$ See, e.g., David R. Tillinghast, A Matter of Definition: 'Foreign' and 'Domestic' Taxpayers, 2 INT'L TAX \& BUS. L 239, 260 (1984).

${ }^{125}$ See, e.g., Michael S. Kirsch, Taxing Citizens in a Global Economy, 82 N.Y.U. L. ReV. 443, 46567 (2007)

${ }^{126}$ See, e.g., Reuven S. Avi-Yonah, Tax Competition and the Trend Toward Territoriality (University of Michigan Public Law, Working Paper No. 297, 2012).

${ }^{127}$ See, e.g., David Elkins, The Myth of Corporate Tax Residence, 9 Colum. J. TAx L. 5 (2017).

${ }^{128}$ Geoffrey Loomer, The Disjunction between Corporate Residence and Corporate Taxation: Is Improvement Possible, 63 CAN. TAX J. 91 (2015).

129 See Hugh J. Ault \& Brian J. Arnold, Comparative Income taxation: A Structural ANALysis 495-526 (3rd ed. 2010); John Prebble, Ectopia, Tax Law and International Taxation, 5 BRIT. TAX REV. 383, 386 (1997); Alex Easson, Common Law Approaches to the Determination of the Source of Income: Pragmatism over Principle, 60 Bull. INT'L TAXATION 495 (2006).

130 The permanent establishment model imposes two constraints on taxation at source. First, source states may only tax non-resident corporations if the corporation has a permanent establishment in the country and, second, source-based taxation is limited to the income attributable to that permanent establishment. See OECD, Model Tax Convention on Income AND on Capital 116-69, 173-218 (2017); Arthur Cockfield, Reforming the Permanent Establishment Principle Through a Quantitative Economic Presence Test, 38 CAN. BUS. L.J. 400 (2003) (providing historical evolution of the concept of permanent establishment and noting its arbitrariness despite practical usefulness). For a critical view of permanent establishment from the perspective 
of profits among jurisdictions also builds on concepts such as transfer pricing and arm's length standards that require a significant degree of stipulation and are subject to varying accounting methods that lead to significantly different distributional outcomes. ${ }^{131}$ The digitalization of the economy in recent decades further compounds the problem. ${ }^{132}$ Recent difficulties in aligning tax jurisdictions with the location of economic activity and recent attempts by the OECD to update rules for nexus and profit attribution for the digitalized economy also point to a significant arbitrariness in how entitlement to tax is assigned. ${ }^{133}$

All of these difficulties demonstrate that the effectiveness of existing tax concepts in asserting tax entitlement is limited. They have been historically useful in determining international tax rules, but the increasing complexity-and, more importantly, arbitrariness - involved in redefining and adapting them to the present reality reveals the limitations of entitlement approaches as normatively justified tools to determine allocation. ${ }^{134}$ These limitations make it difficult to justify an allocation of the international tax base solely on the basis of sovereignty or economic allegiance. When these entitlement approaches fail to accurately determine how rights should be normatively distributed, some other normative criterion is required to address their shortcomings. ${ }^{135}$

of developing countries, see Sergio André Rocha, Should Developing Countries Include Article 7 in Their Tax Treaties?, 71 BULL. INT'L TAXATION 354 (2017).

${ }^{131}$ See Michael Mazerov, Why Arm's Length Falls Short, 5 InT'L TAX REV. 28 (1994); Reuven S. Avi-Yonah, The Rise and Fall of Arm's Length: A Study in the Evolution of U.S. International Taxation, 15 VA. TAX REV. 89 (1995); see also Yariv Brauner, Between Arm's Length and Formulary Apportionment, in The Allocation of Multinational Business Income: Reassessing the Formulary Apportionment OPTION $\S 8.01$ (Rick Krever \& François Vaillancourt eds., 2020) (pointing out the complexity and costliness of arm's length standard-based transfer pricing for developing countries).

${ }^{132}$ See, e.g., Alessandro Turina, Which 'Source Taxation' for the Digital Economy?, 46 INTERTAX 495 (2018); Yariv Brauner, Taxing the Digital Economy Post-BEPS, Seriously, 46 INTERTAX 462 (2018).

${ }^{133}$ See, e.g., Michael P. Devereux \& John Vella, Are We Heading towards a Corporate Tax System Fit for the 21st Century?, 35 Fiscal Stud. 449 (2014); Allison Christians, Taxing According to Value Creation, 90 TAX Notes INT'L 1379 (Jun. 18, 2018); Allison Christians \& Laurens van Apeldoorn, Taxing Income where Value is Created, 22 Fla. TAx Rev. 1 (2018); J. Scott Wilkie, The Way We Were? The Way We Must Be? The 'Arm's Length Principle' Sees Itself (for What It Is) in the 'Digital' Mirror, 47 InTERTAX 1087 (2019); Ruth Mason, The Transformation of International Tax, 114 AM. J. INT'L L. 353 (2020). For the OECD's work on addressing the digitalization of the economy, see OECD, Programme of Work to Develop a Consensus Solution to the Tax Challenges Arising from the Digitalisation of the ECONOMY: Inclusive FRAMEWORK ON BEPS (2019), https://www.oecd.org/tax/beps/programme-of-work-to-develop-a-consensussolution-to-the-tax-challenges-arising-from-the-digitalisation-of-the-economy.pdf [https://perma.cc/7HEXTM3N] [hereinafter, OECD, Programme of Work]; OECD, SECretariat Proposal FOR a "Unified APPROACH" UNDER Pillar ONE: Public CONSUltation Document ( 2019), https://www.oecd.org/tax/beps/public-consultation-document-secretariat-proposal-unified-approach-pillarone.pdf [https://perma.cc/CV3G-B6RF] [hereinafter, OECD, Secretariat Proposal]; OECD, STATEMENT BY THE OECD/G20 Inclusive Framework on BEPS on the Two Pillar Approach to Address the TaX Challenges ARISING FROM the Digitalisation OF THE ECONOMY (2020), https://www.oecd.org/tax/beps/statement-by-the-oecd-g20-inclusive-framework-on-beps.htm [https://perma.cc/A2VF-JLS9].

${ }^{134}$ For analyses pointing to the problematic normative underpinnings of entitlement approaches for assigning tax jurisdiction, see Hugh J. Ault \& David P. Bradford, Taxing International Income: An Analysis of the US System and Its Economic Premises, in TAXation In the Global Economy 11, 30 (Assaf Razin \& Joel Slemrod, eds., 1990) (arguing that "[t]he idea that income has a locatable source seems to be taken for granted, but the source of income is not a well-defined economic idea"); Wei Cui, Minimalism about Residence and Source, 38 Mich. J. INT'L L. 245 (2017) (pointing to the insufficiency of the concepts of source and residence and arguing they require additional considerations such as tax enforceability and normative objectives).

${ }^{135}$ See Stewart, supra note 32, at 307-09 (noting that the increasing reconfiguration of the concepts of source and residence should lead to a differential approach to international taxation). 
Taking the insufficiency of entitlement approaches as an uncontested feature of the current international tax system, a dual conception of inter-nation equity entails what might be called the differential principle, ${ }^{136}$ according to which:

1. states are entitled to tax income generated in their territories or arising from the resources they control - the entitlement component; and

2. whenever allocation according entitlement cannot be asserted unambiguously, taxing rights should be assigned on the basis of differentiation so as to promote international distributive justice-the differential component.

Whenever an entitlement approach is unable to accurately determine where income should be allocated or how much of it should be allocated to different jurisdictions, a decision about allocation requires additional moral judgment to be regarded as normatively legitimate. In the absence of clear moral criteria, such a decision will be made by either some form of dispute resolution or political negotiation. If the former is adopted, a purportedly technical solution will eventually conceal a political or moral judgment, ${ }^{137}$ since a straightforward answer based on entitlement is, in this case, unavailable. If the latter is adopted, the final decision will inevitably be made on the basis of influence and power, and the resulting allocation of rights will ultimately favor more powerful countries, compounding the problem of global inequality. ${ }^{138}$ Both alternatives are problematic because they lack a sound normative basis. In the absence of a justifiable normative criterion for allocating taxing rights, priority should be given to a solution that promotes, rather than departs from, distributive justice.

A controversial aspect of the differential principle might be determining the meaning of "unambiguously" (in proposition 2) since the term establishes the threshold from which the differential component departs. This determination requires settling the degree of failure of the entitlement approach with which we can come to terms. On one end of the spectrum, one could tolerate an absolute degree of failure and take the existing proxies for entitlement as acceptable from a normative standpoint. This is the view implicitly adopted, for example, by those who consider that the current allocation of taxing rights is normatively justified. The main problem with taking this stance is that the more complex it is to determine the underlying factors that contribute to the generation of income, the more inaccurate entitlement approaches are in establishing proxies. It follows that these proxies become increasingly arbitrary. On the opposite end, one could be as strict as to

${ }^{136}$ Despite the lexical similarity, the differential principle proposed in this Article should not be confused with Rawls's difference principle, which is significantly distinct in scope and content.

${ }^{137}$ For a discussion of the relevance of political and moral biases in legal interpretation, see, for example, Gillian K. Hadfield, Bias in the Evolution of Legal Rules, 80 GEO. L.J. 583 (1992); Eric A. Posner, Does Political Bias in the Judiciary Matter?: Implications of Judicial Bias Studies for Legal and Constitutional Reform, 75 U. CHI. L. REV. 853 (2008); Jill Anderson, Misreading Like a Lawyer: Cognitive Bias in Statutory Interpretation, 127 HARV. L. REV. 1521 (2014).

${ }^{138}$ For a discussion about how influence and power affect matters of distributive justice in international tax policy, see Ivan Ozai, Two Accounts of International Tax Justice, 33 CAN. J.L. \& JUR. 317 (2020). Hugh Ault identifies two distinct strands of tax competition. Besides the more commonly observed competition for investment, the recent disagreements about how to allocate taxing rights to deal with the challenges posed by the digitalization of the economy has unveiled the concurrent competition for revenues, which despite being largely unnoted, goes back to the work of the League of Nations in the 1920s. See Hugh J. Ault, Tax Competition and Tax Cooperation: A Survey and Reassessment, in InTERNATIONAL TAXATION IN a Changing Landscape: Liber Amicorum in Honour of Bertil Wiman 1 (Jérôme Monsenego \& Jan Bjuvberg eds., 2019). 
conclude that any entitlement approach will be arbitrary to some degree and that therefore any entitlement approach must be replaced by some other normatively justified approach. ${ }^{139}$ The main problem with this stance is that it fails to acknowledge the normative validity of origin-based theories and the importance of state sovereignty in today's state of affairs. If one is to stand, however, somewhere in the middle of these two extremes, it is difficult to draw a bright-line test for when to shift from an origin-based to a differential approach. A pragmatic solution is to begin by applying the differential approach in cases where the failure of origin-based criteria is most evident. Part IV.C will consider a few cases where entitlement approaches are ineffective to a sufficient degree and should therefore trigger a differential approach.

This section offered a solution for reconciling the entitlement and the differential components of inter-nation equity by addressing the question of when a differential approach should apply to the allocation of taxing rights. The remaining question is how a differential approach should operate, which is the focus of the following section.

B. Requirements for Differentiation

Differentiation has been used in different areas of international law. Yet, both the literature and the real-world applications of differential treatment do not provide straightforward normative requirements that could apply to interjurisdictional differentiation to ensure that it promotes international distributive justice. Nonetheless, based on the normative objectives and underpinnings of differentiation, this section will put forward three core requirements of a legitimate use of this mechanism in international tax policy design.

Universality. The first requirement is a version of horizontal equity, but applied to the international domain. ${ }^{140}$ Since the primary goal of differentiation is to promote international equity, a differential regime that includes some but excludes other states that are equally in need of resources is normatively problematic. One example is a policy that aims at improving the position of low-income countries by using a differentiating factor that favors some of them but excludes others that do not qualify according to that factor. As Part IV.B will discuss, some recent proposals to reform the international tax regime draw on economic impact assessments to argue that a given policy is likely to favor low-income countries which have a specific attribute (such as being rich in natural resources or in labor supply). The main problem with this approach is that it fails to include other countries that are equally poor but do not possess the attribute chosen for differentiation. It might improve vertical equity (by reducing overall inequality between more and less affluent countries), but such improvement comes at the detriment of horizontal equity (by creating further inequalities between equally low-income countries).

139 This case is made, for example, in Adam Kern, Illusions of Justice in International Taxation, 48 Phil. \& PuB. AfF. 151 (2020).

140 The terms horizontal and vertical equity appear frequently in the economics literature to refer to the moral requirement of treating equals equally and unequals unequally, respectively. For a discussion about the relationship between these two notions, see Paul R. McDaniel \& James R. Repetti, Horizontal and Vertical Equity: The Musgrave/Kaplow Exchange, 1 FLA. TAX REV. 607 (1993). These concepts, used as measures of equity between individuals in a domestic context, are rarely used to describe equity between nations. Even when used to describe equity between nations, commentators employ the terminology without much elaboration on the concept. See, e.g., Yoram Margalioth, Tax Competition, Foreign Direct Investments and Growth: Using the Tax System to Promote Developing Countries, 23 VA. TAx ReV. 157, 202 (2003); Adam H. Rosenzweig, Harnessing the Costs of International Tax Arbitrage, 26 VA. TAX REV. 555 (2007); Reuven S. Avi-Yonah \& Yoram Margolioth, Taxation in Developing Countries: Some Recent Support and Challenges to the Conventional View, 27 VA. TAX REV. 1 (2007). 
Universality also favors a multilateral approach in place of the bilateralism that is prevalent in the current international tax system. Besides for the other problems with bilateral tax treaties, largely documented in the tax literature, ${ }^{141}$ bilateralism is also problematic for leaving weaker states susceptible to power imbalances ${ }^{142}$ and resulting in a non-universal regime. ${ }^{143}$ Part IV.B will show that differential approaches taken through bilateralism, such as tax sparing provisions, are problematic among other reasons for their non-universal nature.

Granularity. This requirement builds on the notion of vertical equity. ${ }^{144}$ Differential mechanisms should provide countries in unequal positions with distinct treatment. This requirement disapproves of differential regimes that fit low-income countries into generalizing categories such as developing countries, least developed economies, transition economies, newly industrialized countries, and small island developing states. This approach is normatively problematic not only because of the practical hurdles, such as disputes regarding which category a particular country should be placed in, particularly in borderline cases, ${ }^{145}$ but also because it disregards relevant inequalities within the group and thereby limits the ability of the differential regime to efficiently achieve its normative goal. ${ }^{146}$ Taxing rights are rivalrous goods, and so their availability for allocation to developing countries through differentiation is limited. ${ }^{147} \mathrm{~A}$ differential mechanism that allocates the same share of rights to countries with significantly different levels of development reduces the share that would be available to the ones in the

${ }^{141}$ See, e.g., Michael Rigby, A Critique of Double Tax Treaties as a Jurisdictional Coordination Mechanism, 8 Austl. Tax F. 303 (1991); John F. Avery Jones, Are Tax Treaties Necessary, 53 Tax L. ReV. 1 (2000); Victor Thuronyi, International Tax Cooperation and a Multilateral Treaty, 26 BROOK. J. INT'L L. 1641 (2000); Ricardo García Antón, The 21st Century Multilateralism in International Taxation: The Emperor's New Clothes?, 8 WORLd TAX J. 147 (2016); Vincent Arel-Bundock, The Unintended Consequences of Bilateralism: Treaty Shopping and International Tax Policy, 71 INT'L ORG. 349 (2017).

${ }^{142}$ See Ivan Ozai, Institutional and Structural Legitimacy Deficits in the International Tax Regime, 12 World Tax J. 53 (2020); Tsilly Dagan, The Tax Treaties Myth, 32 N.Y.U. J. InT'L L. Pol'Y. 939 (2000); Kim Brooks \& Richard Krever, The Troubling Role of Tax Treaties, in TAX DESIGN Issues WorLdWIDE 159 (Geerten M.M. Michielse \& Victor Thuronyi eds., 2015); Yariv Brauner, The True Nature of Tax Treaties, 74 BULL. INT'L TAXATION 28 (2020).

${ }^{143}$ See Musgrave \& Musgrave, supra note 3, at 79-80 (arguing that international tax policy should not be left to purely bilateral agreements but should be based on an internationally agreed-upon framework). A similar case made by Philippe Cullet regards the use of equity in international law. One pitfall of differentiation made by judicial equity, such as adopted by the International Court of Justice - the same as any solution limited to individual cases - is its incapacity to consider structural inequalities in the medium and long term, in contrast to structural reform that moves away from the idea of strict reciprocity. See Philippe Cullet, Differential Treatment in Environmental Law: Addressing Critiques and Conceptualizing the Next Steps, 5 TRANSNAT'L ENVIRON. L. 305, 308 (2016).

${ }^{144}$ This granularity requirement, however, is less demanding than vertical equity. Vertical equity, as applied to the distribution of tax burdens between nationals, is frequently deemed to warrant progressivity. The granularity requirement discussed here does not go that far. For a discussion of the relationship between vertical equity and progressivity in domestic settings, see C. Eugene Steuerle, And Equal (Tax) Justice for All?, in TAX Justice: The Ongoing Debate 253 (Joseph J. Thorndike \& Dennis J. Ventry eds., 2002).

${ }^{145}$ See Kristin Bartenstein, De Stockholm à Copenhague : genèse et évolution des responsabilités communes mais différenciées dans le droit international de l'environnement, 56 McGILL L.J. 177, 212 (2010).

146 See Patrícia Galvão Ferreira, Differentiation in International Environmental Law: Has Pragmatism Displaced Considerations of Justice?, in Global ENVIRONMENTAL CHANGE AND INNOvation IN InTERNATIONAL LAW 21 (Neil Craik et al. eds., 2018) (noting the need to consider the growing South-South differences in interests and values in future differential policy design).

${ }^{147}$ The discussion on the allocation of resources (in this case, taxing rights) presupposes scarcity. For a historical analysis of the role of the concept of scarcity in political economy, see Raphael Sassower, Scarcity and Setting the Boundaries of Political Economy, 4 Soc. EPISTEMOLOGY 75 (1990). 
lowest position had a more granular approach (where each country is differentiated individually rather than as part of a group) been applied. ${ }^{148}$ A less practical but normatively superior approach would be to differentiate each country individually rather than as part of a group.

Consistency. The third normative requirement is in part a logical corollary of the previous one. Since differentiation aims to address a certain type of inequality, whether economic, political, geographical, any mechanism used for differentiation should conform to (1) its targeted inequality and (2) its regulatory context. Regarding (1), if differentiation is used to reduce economic inequality between countries, a mechanism that differentiates countries based on a factor that is disproportionate to their actual levels of economic development is problematic. Part IV.C will show that a few reform proposals purportedly aimed at improving taxing rights allocation to low-income countries fail to meet this normative requirement. Regarding (2), if the context in which the differential norm is designed has specific normative goals, the differentiating factor should take those goals into consideration. One prominent example comes from climate change. Besides economic considerations, differential treatment in climate law might additionally require social and environmental considerations to identify the vulnerability of states and their resilience to environmental problems. ${ }^{149}$

\section{Practical Implications}

Differentiation seems to have been implicitly embraced in the international tax system to some degree. Despite the absence of clear normative underpinnings for its application in tax policy, some mechanisms adopted in international tax law clearly take a differential approach by specifically targeting the improvement of the position of less affluent countries. This section will submit that, despite their laudable intent, some of these initiatives are normatively problematic because they fail to meet the basic normative requirements for differentiation.

\section{Tax Sparing Agreements}

Although in disuse in today's treaty negotiations, tax sparing provides one of the most visible forms of differentiation in international taxation, notably when applied to an asymmetrical agreement between developed and developing countries. ${ }^{150}$ Developing countries often offer tax incentives as a way to attract foreign investors. Such incentives involve either reduced tax rates or exemptions. However, the main goal of these incentives is defeated whenever the developed country where the investor resides taxes the low-taxed or untaxed income earned by its resident. Through a tax sparing agreement, a developed country commits to "spare" the tax that it would otherwise impose, thus preserving the economic benefits of tax incentives provided by the developing country to foreign investors.

Some have voiced a firm defense of tax sparing mechanisms from a normative point of view, praising it as a meaningful and necessary mechanism for international redistribution. ${ }^{151}$ However, the adoption of tax sparing provisions has largely decreased since 1999, in part as result of a negative view of the mechanism by the OECD in its 1998

${ }^{148}$ Yet, the differential regimes in place today rarely fulfill this requirement. See Cullet, supra note 143, at 317-19 (noting that most of the existing differential treatment provisions in international law are still based on classification systems that essentially divide the world in North and South).

${ }^{149}$ Id.; see also Ferreira, supra note 146.

${ }^{150}$ Tax sparing has also been used as a reciprocal mechanism between countries with similar trade and investment volumes or close political connections. See Na Li, The Tax Sparing Mechanism And Foreign DIRECT INVESTMENT 44-46 (2019).

${ }^{151}$ See, e.g., Li, supra note 23 , at 128-29. 
tax sparing report. ${ }^{152}$ Other explanations for its decline are a widespread recognition that tax sparing provisions allow for abuses by multinational corporations through tax avoidance strategies, ${ }^{153}$ the lack of evidence that tax sparing increases foreign investment, ${ }^{154}$ and the fact that tax sparing clauses often require low-income countries to make relevant concessions in exchange. ${ }^{155}$

The normative framework put forth in Part IV.B for differentiation suggests that tax sparing is problematic as a differential mechanism. Because only developing countries that are able to secure a tax sparing agreement benefit from the mechanism, tax sparing does not meet the universality requirement for differentiation. Non-universality results in part from the bilateral context from which it arises. At the same time, it is an underlying condition for tax sparing to work, since a comprehensive application of the mechanism would in great part defeat its effectiveness. ${ }^{156}$ Tax sparing also fails to meet the consistency requirement. Since negotiation of tax treaty clauses significantly depends on political negotiation and other contextual factors, the global redistribution effected by tax sparing is strikingly arbitrary from a normative point of view. ${ }^{157}$ Additionally, tax sparing agreements encourage a competitive environment that generally leads to the erosion of tax bases and might make low-income countries that do not have similar agreements even worse-off as a result. Again, this points to the need for universality in differential mechanisms. ${ }^{158}$

\section{Unitary Taxation with Formulary Apportionment}

One proposal prominently advanced in tax policy circles to tackle the differential component of inter-nation equity is to shift how profits earned by multinational corporations are allocated among jurisdictions. Many scholars have called for a departure from separate accounting under the arm's length principle toward a unitary taxation system with formulary apportionment. A unitary taxation system would apportion multinationals'

152 OECD, TAX SPARING: A RECONSIDERATION (1998).

${ }^{153}$ Deborah Toaze, Tax Sparing: Good Intentions, Unintended Results, 49 CAN. TAX J. 879 (2001).

${ }^{154}$ See, e.g., Allison Christians, Tax Treaties for Investment and Aid to Sub-Saharan Africa: A Case Study, 71 Brook. L. ReV. 639, 693-94 (2005); William B. Barker, An International Tax System for Emerging Economies, Tax Sparing, and Development: It Is All about Source, 29 U. PA. J. InT'L L. 349, 388 (2007) (describing one reason as being due to the fact that tax sparing decreases investment in low-income countries by encouraging repatriation); Kim Brooks, Tax Sparing: A Needed Incentive for Foreign Investment in LowIncome Countries or an Unnecessary Revenue Sacrifice, 34 QuEEN's L.J. 505, 555-56 (2009); but see James R. Hines Jr, Tax Sparing and Direct Investment, in DEVELOPING CoUnTRIES INTERNATIONAL TAXATION AND Multinational ACTIVITY 39 (James R. Hines Jr. ed., 2000) (demonstrating some positive correlation between tax sparing and foreign direct investment increase); Céline Azémar, Rodolphe Desbordes \& Jean-Louis Mucchielli, Do Tax Sparing Agreements Contribute to the Attraction of FDI in Developing Countries?, 14 INT'L TAX \& PUB. FIN. 543 (2006).

${ }^{155}$ Developing countries might have to accept, for example, lower withholding tax rates or stricter permanent establishment rules in exchange for tax sparing. See Richard D. Kuhn, United States Tax Policy with Respect to Less Developed Countries, 32 GEo. WASH. L. REv. 261, 263-64 (1963) (pointing out that tax sparing is negotiated in a quid pro quo context); Hope Ashiabor, Tax Sparing: A Timeworn Mechanism in Australia's Bilateral Treaties with Its Trading Partners in Southeast Asia, 24 InT'L TAX J. 67, 75 (1998).

${ }^{156}$ Because tax sparing aims to favor a given country in its efforts to attract foreign investment through tax holidays, it presupposes that other competing countries do not have a similar advantage. The effectiveness of tax sparing provisions relies in great part precisely on the fact that it is exclusive.

${ }^{157}$ See Brooks, supra note 154, at 557 ("Granting one low-income country a tax sparing arrangement will undoubtedly encourage other such countries to seek similar arrangements with their treaty partners, thereby reducing the advantage any one country has. This inevitably discriminates against low-income countries that have neither the political nor the economic clout to press for tax treaties in the first place, even though they are likely the ones that most need to encourage investment in some fashion.").

${ }^{158}$ See Christians, supra note 154, at 694. 
profits based, partially or entirely, on a multi-factor formula that considers the location of economic factors such as assets, sales, and employees or payroll. The shift toward unitary taxation would eliminate the complexity of transfer pricing rules and associated administrative and compliance costs that currently take a toll on lower-income countries. ${ }^{159}$

One important and challenging aspect of adopting unitary taxation is settling on the formula according to which profits would be allocated among jurisdictions. Since the rights of countries to tax are determined based on how income is allocated, formulary apportionment would significantly change the current distribution of taxing rights. Proposals for formulary apportionment mostly suggest a formula based on a combination of economic factors, such as the location of sales, payroll expenses, and physical assets. Different proposals assign varying weights to each of these economic factors. ${ }^{160}$ Considering the relative arbitrariness according to which such a formula is to be eventually decided (that is, considering the insufficiency of an entitlement approach as normative guidance), ${ }^{161}$ the differential principle stated in Part III.A implies that a differential approach should take priority in determining allocation. ${ }^{162}$

The relevance of a differential approach in formulary apportionment seems to have been recognized in tax policy circles. In a policy paper released in 2014, the International Monetary Fund (IMF) aimed to assess "spillover effects on developing countries of major tax reforms proposed." 163 One of the major concerns presented in the paper is how

${ }^{159}$ Michael C. Durst, The Tax Policy Outlook for Developing Countries: Reflections on International Formulary Apportionment (International Centre for Tax and Development, Working Paper No. 32, 2015).

${ }^{160}$ For a brief analysis of the distributive outcome of different formulas, see Heinz-Klaus Kroppen, Roman Dawid \& Richard Schmidtke, Profit Split, the Future of Transfer Pricing? Arm's Length Principle and Formulary Apportionment Revisited from a Theoretical and a Practical Perspective, in FUNDAMENTALS OF InTERnATIONAL TRANSFer Pricing IN LAW AND ECONOMiCs 267, 273-76 (Wolfgang Schön \& Kai A Konrad eds., 2012).

${ }^{161}$ See Edgar, supra note 4, at 1154 ("[F] ormulary allocation approaches cannot be justified as realizing some correct allocation defined in any precise normative sense.”); Reuven S. Avi-Yonah, Kimberly A. Clausing \& Michael C. Durst, Allocating Business Profits for Tax Purposes: A Proposal to Adopt a Formulary Profit Split, 9 FLA. TAX REV. 497, 516-17 (2009) (acknowledging that any formula can produce arbitrary results in a given industry but arguing that the present separate accounting system is equally or more arbitrary); James R. Hines Jr, Income Misattribution Under Formula Apportionment, 54 EuR. ECON. ReV. 108 (2010) (showing that formulas included in proposals for formulary apportionment are not strongly correlated with determinants of business incomes). The normative arbitrariness is also clear when noted that in countries where a formulary apportionment was adopted to allocate tax base among states, the choice of formula significantly relies on pragmatism rather than on an entitlement approach. In the U.S., states gradually shifted to sales as the main allocating factor, not because of its normative appeal, but because it is less vulnerable to corporations' arbitrage. See Michael Mazerov, Center on Budget and Policy Priorities, The SingleSAlEs-Factor Formula: A Boon to EConomic Development or a Costly Giveawav? (2001) (noting the weak economic rationale behind the shift toward a single-sales-factor formula); Jack Mintz, Europe Slowly Lurches to a Common Consolidated Corporate Tax Base: Issues at Stake, in A COMMON CONSOLIDATED CORPORATE TAX BASE FOR EUROPE 128 (Wolfgang Schön, Ulrich Schreiber \& Christoph Spengel eds., 2008). For some legal implications of a sales-based formula at the international level, see Charles E. Mclure Jr. \& Walter Hellerstein, Does Sales-Only Apportionment of Corporate Income Violate International Trade Rules?, 27 TAX Notes INT'L 1315 (Sep. 9, 2002).

${ }^{162}$ For a similar observation, see Tommaso Faccio \& Valpy Fitzgerald, Sharing the Corporate Tax Base: Equitable Taxing of Multinationals and the Choice of Formulary Apportionment, 25 TRANSNAT'L CORP. 67,85 (2018) (pointing out that the existing formula proposals lack a clear economic rationale and pay insufficient attention to the equitable treatment of developing countries).

${ }^{163}$ InTERnational Monetary Fund, Spillover in InTERnational Corporate TaXation 24 (2014), https://www.imf.org/external/np/pp/eng/2014/050914.pdf [https://perma.cc/CH6F-8QB4]. For a 
different formulas would significantly impact the distribution of tax base to developing countries. Based on an economic impact assessment of how different formulas would impact different groups of countries (divided into advanced, developing, and conduit countries), the paper emphasizes criteria that would favor poorer economies, namely a formula that places heavy weight on employment factors (based on headcount, not wages). ${ }^{164}$

The initiative deserves praise for taking the interests of developing countries into consideration. However, there are some problems with this approach. The first is methodological, since it relies on data with only limited availability. ${ }^{165}$ The second is that, in the absence of a clear economic rationale behind any choice of formula, the distributive consequences of the final decision on the weight of each economic factor in the formula will be concealed under a purportedly technical discussion. ${ }^{166}$ Third, and most importantly from an inter-nation equity perspective, choosing a formula based on the economic impacts on groups of countries violates the normative requirements for differentiation put forth in Part III.B. By analyzing the economic impacts of formulas on three generalized groups of countries (advanced, developing, and conduit countries), the IMF study disregards the fact that the level of development varies within each of these groups. Although some lowincome countries would potentially benefit from a formula based on employment, others might not. A final allocation of multinationals' profits largely based on employment might reduce overall global inequality but would potentially leave many low-income countries unattended, thereby failing to meet the granularity requirement. Additionally, even countries that would benefit from such an approach would likely not benefit in proportion to their development needs because development needs and employment by multinational corporations are not directly correlated. Therefore, such an allocation fails to meet the consistency requirement.

The problem, of course, is not with the IMF's study but rather the idea that the allocation of profits based on one or a set of production factors would offer a fair division of taxing rights. Taking again into consideration the reasonable degree of arbitrariness that a choice of formula involves - in which case the differential principle requires the application of a differential approach - some economic or human development indicator is called for as a contributory factor to the apportionment formula. Including a direct measure of international inequality in the formula is perhaps the only possible way to achieve a universal, granular, and consistent approach. ${ }^{167}$ It would not only be more suitable to

similar conclusion, see Faccio \& Fitzgerald, supra note 162, at 72-73 (noting that developing countries gain from employment factors but lose from payroll factors because wages are much higher in developed countries).

${ }^{164}$ InTERNATIONAL MONETARY FUND, supra note 163, at 39-40.

${ }^{165} I d$., at 40 (stating that data limitations prevent precise calculations); Sol Picciotto, Unitary Alternatives and Formulary Appointment, in TAXING MULTINATIONAL ENTERPRISES AS UNITARY FIRMS 27, 3637 (Sol Picciotto ed., 2017) (emphasizing the lack of data, especially relating to developing countries, for this type of quantification).

${ }^{166}$ For example, it has been noted that capital-importing countries might argue for factors based on destination sales, while capital-exporting states might argue for apportionment focused primarily on aspects relating to residence. See Arthur J. Cockfield, Formulary Taxation Versus the Arm's-Length Principle: The Battle Among Doubting Thomases, Purists, and Pragmatists, 52 CAN. TAX J. 114, 120 (2004).

${ }^{167}$ Although the most common approach would be to use per capita income as a reference, other indexes may be more appropriate to measure and compare international inequality. See Infanti, supra note 23 (arguing for expanding the focus of inter-nation equity beyond economic growth to incorporate other noneconomic considerations, such as feminist, social or strategic ones, and proposing the use of other indexes that include non-economic dimensions as the criteria for a differential approach, such as the Human Development Index (HDI), the Inequality-adjusted HDI (IHDI), Gender Inequality Index (GII), and the UK Department for 
accomplishing inter-nation equity, but would also bring greater transparency regarding normative rationales and distributional outcomes and be less reliant on estimations that frequently suffer from data limitations. ${ }^{168}$

\section{The OECD's "Unified Approach"}

In a project aimed to address the tax challenges arising from the digitalization of the economy, the OECD has put forward, among other measures, a proposal to allocate a portion of multinationals' residual profits to the jurisdictions where customers and users are located, also referred to as "market jurisdictions." 169 The proposal is part of what the OECD has called the "unified approach" and comes as a response to demands from countries with substantial consumer markets to update the current allocation of profits generated by digitalized businesses. ${ }^{170}$ The phrase "unified approach" indicates the OECD's stated goal to achieve a compromise solution that satisfies all conflicting proposals on the table, namely the European Union's focus on user participation, the United States' preference for considering marketing intangibles, and the Group of Twenty-Four's proposal for allocating income based on multinationals' significant economic presence. ${ }^{171}$

The unified approach proposal allocates a share of multinationals' residual profits to market jurisdictions using a formulaic approach. ${ }^{172}$ The distributional impacts of this proposal are, however, unclear. In February 2020, the OECD suggested that it would significantly favor low- and middle-income economies, ${ }^{173}$ but commentators are skeptical about that assertion. ${ }^{174}$ Considering that the OECD's proposal aims to favor countries with

International Development (DFID)). See also Kim Brooks, Global Distributive Justice: The Potential for a Feminist Analysis of International Tax Revenue Allocation, 21 CAN. J. WOMEN \& L. 267 (2009) (arguing that one of the implications of a feminist analysis of international tax policy is the requirement to allocate greater taxing rights to lower-income countries).

${ }^{168}$ Due to the absolute immobility of development indexes to corporate decisions, this approach could also potentially limit tax-avoidance opportunities resulting from formulas that rely on mobile factors.

${ }^{169}$ OECD, Programme of Work, supra note 133, at 11.

${ }^{170}$ OECD, Secretariat Proposal, supra note 133.

${ }^{171}$ For a detailed discussion on the political struggles and distributive implications involving these proposals, see Allison Christians \& Tarcisio Diniz Magalhaes, A New Global Tax Deal for the Digital Age, 67 CAN. TAX J. 1153 (2019).

${ }^{172}$ In addition to this formulaic approach (which the OECD calls Amount A), the unified approach includes a fixed baseline return for routine market-facing activities (Amount B) and incremental return attributable to a jurisdiction when Amount B falls short of the market-based routine return assumed under the application of the arm's-length principle (Amount C). For an overview, see Kartikeya Singh, W Joe Murphy \& Gregory J Ossi, The OECD's Unified Approach - An Analysis of the Revised Regime for Taxing Rights and Income Allocation, 97 TAX NOTES INT'L 549 (Feb. 3, 2020).

${ }^{173}$ See Webcast: Update on Economic Analysis and Impact Assessment, oecd.org/tax/beps/webcasteconomic-analysis-impact-assessment-february-2020.htm [https://perma.cc/2B4E-TE7R]; OECD, Tax Challenges Arising from the Digitalisation of the Economy Update on the Economic Analysis \& Impact Assessment, http://www.oecd.org/tax/beps/presentation-economic-analysis-impact-assessment-webcastfebruary-2020.pdf [https://perma.cc/KX97-ZALE].

${ }^{174}$ See, e.g., Alex Cobham, Tommaso Faccio \& Valpy FitzGerald, Global Inequalities in Taxing Rights: An Early Evaluation of the OECD Tax Reform Proposals (2019), https://osf.io/preprints/socarxiv/j3p48 [https://perma.cc/9KQR-WAZB] (concluding that the reallocation of taxing rights derived from OECD's proposal is likely to reduce revenues for several low-income countries). See also Allison Christians, OECD Digital Economy Designers: Share Your Work!, 97 TAX NoTES INT'L 1251 (Mar. 23, 2020) (noting that the information provided in February 2020 by the OECD was only partial - a webcast and a few slides outlining its findings — and the underlying data that led to these results was not made publicly available, raising questions about transparency and inclusivity). 
larger consumer markets, low-income countries with small consumer markets will hardly benefit from this approach. ${ }^{175}$

More importantly, the same criticisms made above regarding the IMF's approach to unitary taxation apply here. Considering the relative normative arbitrariness according to which the OECD's unified approach was established, the differential principle warrants that a differential approach should take priority in determining allocation. Although the OECD suggests that the new approach would significantly favor low- and middle-income economies, its argument suffers from methodological problems due to limitations in data availability, the absence of clear normative or economic rationale behind the chosen formulary approach, and the lack of transparency that conceals disputes about rights allocation under an apparent technical discussion. But more importantly, the OECD's unified approach fails to meet the normative requirements for a differential approach.

In a context where the transfer pricing regime is maintained, apportioning residual profits on a formulaic basis seems promising. ${ }^{176}$ However, considering that residual profits, by definition, are not directly attributable to any specific jurisdiction, any formula established on the basis of an entitlement approach will largely lack economic rationale and thus be significantly arbitrary. ${ }^{177}$ The lack of normative guidance for allocating residual profits among jurisdictions calls for the application of the differential principle advocated in this Article, which warrants a differential approach in such cases. Similar to the case of unitary taxation discussed above, an appropriate approach to the allocation of residual profits should include some development indicator, such as GDP per capita, as a factor in the apportionment formula. ${ }^{178}$

V. CONCLUSION

Normative discussions on how to distribute tax jurisdictions are frequently met with skepticism. The realist view of international relations, where any agreements on normative principles are based on self-interest and bargaining power, still predominates in tax policy analysis. Yet, there is evidence that governments are, at least to some extent, motivated by a concern with international justice. Initiatives such as the United Nations' Sustainable Development Goals (SDGs), ${ }^{179}$ the OECD's Task Force on Tax and

175 See Christians \& Magalhaes, supra note 171, at 1173-76 (showing that the shift of profits allocation toward location of consumers will mostly benefit countries with larger consumer markets, such as the EU countries, the U.S., and middle-income countries, rather than the lower-income ones). See also Faccio \& Fitzgerald, supra note 162, at 85; INDEPENDENT COMMISSION FOR THE REFORM OF INTERNATIONAL


GLOBAL TAXATION 10 (2018).

${ }^{176}$ See Reuven S. Avi-Yonah \& Ilan Benshalom, Formulary Apportionment-Myths and Prospects: Promoting Better International Tax Policies by Utilizing the Misunderstood and Under-Theorized Formulary Alternative, 3 WORLD TAX J. 371 (2011).

177 See Reuven S. Avi-Yonah, The Rise and Fall of Arm's Length: A Study in the Evolution of U.S. International Taxation, 15 VA. TAX REV. 89, 148-49 (1995) (noting that residual profit, by definition, is the return resulting from the interaction of the constituent parts of a multinational entity and thereby cannot be assigned to respective components without a significant degree of arbitrariness).

${ }^{178}$ For the idea of including a differential approach to the allocation of multinationals' profits, see Musgrave \& Musgrave, supra note 3, at 85 ("[T] he only satisfactory solution . . would be the taxation of such [multinational] income on an international basis with subsequent allocation of proceeds on an apportionment basis among the participating countries, making allowance for distributional considerations.").

${ }^{179}$ G.A. Res. 70/1, 43 (Oct. 21, 2015) (stating that, among other goals, it aims to "mobilize public resources domestically, especially in the poorest and most vulnerable countries with limited domestic resources"). 
Development, ${ }^{180}$ and the inter-agency Platform for Collaboration on Tax ${ }^{181}$ seem to demonstrate a substantial effort to improve economic development in less affluent countries. Additionally, a meaningful concern with international redistribution may encourage cooperation of lower-income countries in undertaking obligations required for a coordinated effort to address the current international tax challenges. Insofar that this is the case, more extended discussions about inter-nation equity should provide normative guidance for an allocation of the international tax base that allows for meaningful redistribution while preserving nations' entitlements.

There is also reason to argue that redistribution through allocation of taxing rights is a viable option compared to alternative policies. For instance, there are doubts as to the effectiveness of development aid, especially considering its potential to exacerbate corruption and reduce incentives to develop sustainable policies. ${ }^{182}$ Foreign aid also often limits recipient countries' fiscal autonomy because donor countries frequently impose direct control over expenditure of aid toward specific projects. ${ }^{183}$ Moreover, redistribution through foreign aid lacks uniformity since the selection of recipients depends on reasons that are fairly arbitrary from a normative perspective, such as close economic ties or geographic proximity. ${ }^{184}$ Compared to differential treatments adopted in other areas of law, differentiation in international tax law also seems to offer a more promising and direct form of redistribution because it entails less distortionary effects. ${ }^{185}$ Improving taxing rights of lower-income countries also contributes to their ability to mobilize revenue, which is a fundamental requirement to finance achievement of sustainable development goals. ${ }^{186}$

${ }^{180}$ OECD, OECD WORK ON TAX AND DEVELOPMENT 32 (2019), http://www.oecd.org/ctp/brochureoecd-work-on-tax-and-development.pdf [https://perma.cc/W8EE-4X6U] (stating that it was established to "build an environment in developing countries that will enable them to collect appropriate and adequate tax revenues and build effective states").

181 The Platform for Collaboration on Tax, Strengthening Tax Capacity in Developing COUNTRIES: INTER-AGENCY PlatForm FOR COLlABORATION ON TAX (2018), https://www.un.org/esa/ffd/wpcontent/uploads/2018/05/2018-ECOSOC-ICTM-SM_Platform_consolidated.pdf [https://perma.cc/WE2GEQCP] (stating that it is a joint collaboration between the IMF, the OECD, the UN, and the World Bank Group established to "facilitate the participation of developing countries in the global dialogue on tax matters" and "strengthen domestic revenue mobilization in developing countries").

182 See Stephen Knack, Does Foreign Aid Promote Democracy?, 48 InT’L STud. Q. 251 (2004) (suggesting that when aid dependence increases as a proportion of government consumption, recipient states will become less accountable for their own actions, and conflicts over aid funds increase); see also Stephen Knack \& Aminur Rahman, Donor Fragmentation and Bureaucratic Quality in Aid Recipients, 83 J. DEV. ECON. 176 (2007).

${ }^{183}$ Stewart, supra note 32, at 304-05.

${ }^{184}$ But see Ilan Benshalom, The New Poor at Our Gates: Global Justice Implications for International Trade and Tax Law, 85 N.Y.U. L. REV. 1, 29 (2010) (arguing that arbitrary geographic proximity may be a factor sufficiently relevant to trigger or intensify duties of justice).

${ }^{185}$ Differential approaches included in specific regulatory frameworks, such as the principle of common but differentiated responsibilities and respective capabilities adopted in the UNFCC (see supra text accompanying notes 102-03), can potentially cause inefficiencies that impact its main goal. The problem does not exist in international taxation, whose fundamental goal is to allocate taxing rights among jurisdictions. See Benshalom, supra note 114, at 338 ("In the international tax context, the distribution of the right to tax is the main objective, and there is no external, common good objective that can be distorted. Because the policy objective of the international tax regime is to achieve sustainable distribution of profits derived from international commerce, there may be less of a dichotomy between redistributive equity and efficiency.").

${ }^{186}$ See U.N. Comm. of Experts on Int'l Cooperation in Tax Matters, The Role of Taxation and Domestic Resource Mobilization in the Implementation of the Sustainable Development Goals, U.N. Doc. E/C.18/2018/CRP.19 (2018); see also Apeldoorn, supra note 91 (arguing that allocating taxing rights in a way that favors low-income states is fundamental to increasing their capacity to mobilize revenue while preventing double taxation that could disturb international investment). 
Recent developments in international tax policy seem to offer an unparalleled opportunity to reconsider the normative justification of long-standing criteria used in the international allocation of taxing rights. ${ }^{187}$ The relevance of multinational corporations and the global changes arising from digitalization have recently impelled a revision of the present distribution of taxing rights, ${ }^{188}$ thus motivating a re-examination of the normative underpinnings for the division of the international tax base. ${ }^{189}$ Claims from countries with large consumer markets - mostly high- and middle-income countries - that a revised global compact should give them a greater share of tax revenues seems to hold valid, but the lack of clear entitlement for a significant portion of the international tax base calls for more sustained normative criteria.

A dual conception of inter-nation equity entails the accommodation of the two normative components of international justice (entitlement and differentiation) in a way that the limitations of the entitlement approach are offset by the differential approach. The differential principle put forward in this Article requires that whenever entitlement to tax cannot be clearly established based on an entitlement approach, determining the allocation of taxing rights should be primarily guided by redistributive goals. Differentiation must meet three main normative requirements: (1) universality, so that it does not shut out countries equally in need; (2) granularity, so that differentiation considers countries individually rather than generalizing them into groups that disregard relevant intra-group inequalities (e.g., developing countries); and (3) consistency, so that rights be assigned in a way that adequately address the targeted inequality that gave rise to a differential approach in the first place. These seemingly evident normative requirements have robust practical implications and proscribe some initiatives that are commonly regarded as favoring lower-income countries.

One may view the normative requirements put forth in this Article as excessively demanding. At the end of the day, it could be argued, any change in the current international tax system that contributes to tilting the scale in favor of lower-income countries should deserve praise and encouragement. Although this may hold some truthpointing to an important difference between duty of assistance and claims of distributive justice-satisfying international justice is not simply about improving the situation of worse-off countries, but also about doing it in a way that is consistent with their needs. The fundamental problem with accepting any differential mechanism as normatively satisfying is that, regardless of normative demands, the agreement of more powerful, affluent countries to redistribution faces political limitations. Without clear normative guidelines

187 See Steven A. Dean, A Constitutional Moment for Cross-Border Taxation (Aug. 25, 2020) (unpublished manuscript), https://www.law.nyu.edu/sites/default/files/A\%20Constitutional\%20Moment \%20in\%20Cross-Border\%20Taxation-\%20Dean_0.pdf [https://perma.cc/W9QQ-Y2LU] (pointing out that for the first time in decades, international tax policy has entered a fluid phase in which fundamental reform becomes possible, and warning for the urgency in recognizing the opportunity for critical improvements before the moment passes); Mason, supra note 133, at 401.

${ }^{188}$ See OECD, AdDREssing the Tax Challenges of the Digitalisation of the ECONOMy (2019), https:/www.oecd.org/tax/beps/public-consultation-document-addressing-the-tax-challenges-of-thedigitalisation-of-the-economy.pdf [https://perma.cc/RQW5-Z6Q8]. For an overview of the context and political motivations of the OECD's efforts to address this issue, see Allison Christians \& Magalhaes, supra note 171 .

${ }^{189}$ See, e.g., Christians \& Apeldoorn, supra note 133; Michael P. Devereux \& John Vella, Value Creation as the Fundamental Principle of the International Corporate Tax System (European Tax Policy Forum, Working Paper, 2018); Wolfgang Schön, One Answer to Why and How to Tax the Digitalized Economy, 47 Intertax 1003 (2019); Wilkie, supra note 133; Svitlana Buriak, A New Taxing Right for the Market Jurisdiction: Where Are the Limits?, 48 INTERTAX 301 (2020). 
for meaningful redistribution, promotion of suboptimal initiatives might prevent the consideration of normatively superior ones. Or, as a more cynical view may suggest, the absence of criteria for appropriate redistribution may lead to the opportunistic use of modest or unsatisfactory concessions to excuse the lack of more significant initiatives.

At a time when governments struggle with the more immediate domestic concern of fighting a global pandemic and an upcoming economic crisis, it might seem futile to argue for placing attention on normative demands to address international inequality in the international tax system. Yet, if there are valid reasons for embracing aspirations for justice in times of stability, this becomes even more pressing during a recession, when the global poor will inevitably bear a greater burden. 